\title{
Year-round record of bulk and size-segregated aerosol composition in central Antarctica (Concordia site) - Part 2: Biogenic sulfur (sulfate and methanesulfonate) aerosol
}

\author{
Michel Legrand ${ }^{1,2}$, Susanne Preunkert $^{1,2}$, Rolf Weller $^{3}$, Lars Zipf $^{4}$, Christoph Elsässer $^{4}$, Silke Merchel $^{5}$, \\ Georg Rugel $^{5}$, and Dietmar Wagenbach ${ }^{4, \dagger}$ \\ ${ }^{1}$ Université Grenoble Alpes, Institut des Géosciences de l'Environnement (IGE), \\ Grenoble, 38402, France \\ ${ }^{2}$ CNRS, Institut des Géosciences de l'Environnement (IGE), Grenoble, 38402, France \\ ${ }^{3}$ Alfred Wegener Institut für Polar und Meeresforschung, Bremerhaven, 27570, Germany \\ ${ }^{4}$ Institut für Umweltphysik, University of Heidelberg, Heidelberg, 69120, Germany \\ ${ }^{5}$ Helmholtz-Zentrum Dresden-Rossendorf (HZDR), Dresden, 01328, Germany \\ $\dagger$ deceased, December 2014 \\ Correspondence to: Michel Legrand (michel.legrand@univ-grenoble-alpes.fr)
}

Received: 1 April 2017 - Discussion started: 11 April 2017

Revised: 20 October 2017 - Accepted: 26 October 2017 - Published: 24 November 2017

\begin{abstract}
Multiple year-round (2006-2015) records of the bulk and size-segregated composition of aerosol were obtained at the inland site of Concordia located in East Antarctica. The well-marked maximum of non-seasalt sulfate $\left(\mathrm{nssSO}_{4}\right)$ in January $\left(100 \pm 28 \mathrm{ng} \mathrm{m}^{-3}\right.$ versus $4.4 \pm 2.3 \mathrm{ng} \mathrm{m}^{-3}$ in July) is consistent with observations made at the coast $\left(280 \pm 78 \mathrm{ng} \mathrm{m}^{-3}\right.$ in January versus $16 \pm 9 \mathrm{ng} \mathrm{m}^{-3}$ in July at Dumont d'Urville, for instance). In contrast, the well-marked maximum of MSA at the coast in January $\left(60 \pm 23 \mathrm{ng} \mathrm{m}^{-3}\right.$ at Dumont d'Urville) is not observed at Concordia $\left(5.2 \pm 2.0 \mathrm{ng} \mathrm{m}^{-3}\right.$ in January). Instead, the MSA level at Concordia peaks in October $\left(5.6 \pm 1.9 \mathrm{ng} \mathrm{m}^{-3}\right)$ and March $\left(14.9 \pm 5.7 \mathrm{ng} \mathrm{m}^{-3}\right)$. As a result, a surprisingly low MSA-to-nssSO $\mathrm{S}_{4}$ ratio $\left(\mathrm{R}_{\mathrm{MSA}}\right)$ is observed at Concordia in mid-summer $(0.05 \pm 0.02$ in January versus $0.25 \pm 0.09$ in March). We find that the low value of $\mathrm{R}_{\text {MSA }}$ in mid-summer at Concordia is mainly driven by a drop of MSA levels that takes place in submicron aerosol $(0.3 \mu \mathrm{m}$ diameter $)$. The drop of MSA coincides with periods of high photochemical activity as indicated by high ozone levels, strongly suggesting the occurrence of an efficient chemical destruction of MSA over the Antarctic plateau in mid-summer. The relationship between MSA and $\mathrm{nssSO}_{4}$ levels is examined separately for each season and indicates that concentration of non-biogenic sulfate over the Antarctic
\end{abstract}

plateau does not exceed $1 \mathrm{ng} \mathrm{m}^{-3}$ in fall and winter and remains close to $5 \mathrm{ng} \mathrm{m}^{-3}$ in spring. This weak non-biogenic sulfate level is discussed in the light of radionuclides $\left({ }^{210} \mathrm{~Pb}\right.$, ${ }^{10} \mathrm{Be}$, and ${ }^{7} \mathrm{Be}$ ) also measured on bulk aerosol samples collected at Concordia. The findings highlight the complexity in using MSA in deep ice cores extracted from inland Antarctica as a proxy of past dimethyl sulfide emissions from the Southern Ocean.

\section{Introduction}

The coupling between climate and atmospheric aerosol involves complex processes that are not yet fully elucidated. In the southern hemisphere, aside from the primarily emitted sea-salt particles, the oxidation of dimethyl sulfide (DMS) emitted by phytoplankton is an important source of secondary aerosol (Gondwe et al., 2003). In the atmosphere, DMS is oxidized into small sulfate and methanesulfonate aerosols that interact with solar radiations reaching Earth's surface by scattering of solar energy and by acting as condensation nuclei for cloud droplets, thereby affecting the cloud albedo (Shaw, 1983; Charlson et al., 1987).

Polar ice cores provide a unique archive of climate and past atmospheric aerosol (composition and load) that may 
help to address some relevant key questions (Legrand and Mayewski, 1997). In contrast to sulfate, methanesulfonate (MS $^{-}$, also denoted MSA) is exclusively formed by photooxidation of DMS. Pioneering studies dedicated to its records extracted from Antarctic ice cores proposed its use to investigate changes of the marine biota in response to past climatic fluctuations (Legrand and Feniet-Saigne, 1991; Legrand et al., 1991) or sea-ice extent (Welch et al., 1993; Curran et al., 2003). However, it rapidly appears that the interpretation of MSA ice core profiles in terms of past oceanic DMS emissions is far less straightforward than initially thought. First, highly complex mechanisms control the DMS marine emissions. For instance, it is now recognized that the concentration and the oceanic emission of DMS is controlled not only by the phytoplankton biomass or activity alone but also by numerous ecological and biogeochemical processes that are not well understood (Simo' and Dachs, 2002). Second, the atmospheric behavior of DMS, which is characterized by a variable MSA oxidation yields (Gondwe et al., 2004), renders more difficult than expected the use of the ratio of MSA to non-sea-salt sulfate ( $\mathrm{R}_{\mathrm{MSA}}$ ) to separate the contribution of marine biogenic emissions from other sulfate sources like volcanic activity, terrestrial sources, and possibly the stratospheric sulfate reservoir. It is now well recognized that $\mathrm{R}_{\mathrm{MSA}}$ is highest in the polar region and lowest within the tropics due to a more efficient MSA production from the $\mathrm{OH}$ oxidation of DMS at low temperatures (Bates et al., 1992; Gondwe et al., 2004). However, at very high latitudes the atmospheric behavior of DMS may be even more complex than elsewhere due to the presence of halogenated radicals (Read et al., 2008) and a possible role of heterogeneous chemistry on the behavior of dimethyl sulfoxide (DMSO) (Davis et al., 1998). Whereas a good relationship between the MSA level in air and fresh snow has been observed (Jaffrezo et al., 1994; Wolff et al., 1998), the existence of post-depositional losses and migration of MSA signals within annual firn layers have been recognized by several studies (Wagnon et al., 1999; Pasteur and Mulvaney, 2000; Delmas et al., 2003; Weller et al., 2004). Concerning the loss of MSA from the Antarctic snowpack towards the atmosphere, the subsequent presence of MSA in the gas phase is, however, still unclear (Weller et al., 2004; Piel et al., 2006; Mauldin et al., 2004). This loss of MSA was proposed to explain the previous observations of a decreasing trend of $\mathrm{R}_{\mathrm{MSA}}$ in snow deposited at the coast compared to inland Antarctica (Legrand, 1997). Finally, the calculations of the non-sea-salt sulfate present in Antarctica are more difficult than at any other place in the world due to a depletion of sulfate relative to sodium caused by precipitation of mirabilite $\left(\mathrm{Na}_{2} \mathrm{SO}_{4} \cdot 10 \mathrm{H}_{2} \mathrm{O}\right)$ during freezing of seawater in winter (Wagenbach et al., 1998).

To explain these phenomena, atmospheric records of both DMS and sulfur aerosol are needed, particularly in the vicinity of sites where Antarctic ice cores are extracted. While detailed long-term records of sulfur-derived aerosol species (sometimes completed by DMS and DMSO measurements) are available for the coastal sites of Neumayer (NM) and Dumont d'Urville (DDU) (Wagenbach, 1996; Minikin et al., 1998; Jourdain and Legrand, 2001), only very scattered atmospheric observations of both MSA and sulfate have been obtained so far at central Antarctic positions. Except the study conducted at Concordia by Preunkert et al. (2008) covering a complete annual cycle of MSA, non-sea-salt sulfate, and DMS, most inland records were restricted to austral summer with only few data obtained during polar night (Arimoto et al., 2001, 2004, 2008; Udisti et al., 2004; Piel et al., 2006).

We here report on multiple year-round (2006-2015) records of bulk aerosol composition of sulfur-derived aerosol (MSA and sulfate) at the Concordia site located on the high East Antarctic plateau. The record of bulk aerosol is complemented by a study of the size-segregated aerosol composition conducted by running a 12-stage impactor over 3 years (2009-2011). As discussed in the companion paper (Legrand et al., 2017), these impactor data are essential to evaluate the degree of sulfate depletion relative to sodium of sea-salt aerosol in winter and consequently to accurately calculate here the nssSO 4 level and the $\mathrm{R}_{\mathrm{MSA}}$ ratio. Here we present and discuss the temporal variability of the composition of sulfur-derived aerosol (MSA, non-sea-salt sulfate, and $\mathrm{R}_{\mathrm{MSA}}$ ) and its dependence to the aerosol size in relation to seasonal change of marine biogenic DMS emissions and the contribution of non-biogenic sources of sulfate.

\section{Sites, samplings and methods}

Bulk aerosol sampling was initiated in 2006 at the inland site of Concordia $\left(75^{\circ} 06^{\prime} \mathrm{S}, 123^{\circ} 20^{\prime} \mathrm{E}\right.$; $3233 \mathrm{~m}$ a.s.l.) located near Dome C (DC; $1100 \mathrm{~km}$ away from the nearest coast of East Antarctica). Working conditions are detailed in Legrand et al. (2017). Given the weekly sampling time, a large air volume was sampled $\left(\sim 8000 \mathrm{~m}^{3}\right)$, permitting the blank values to remain well below $1 \mathrm{ng} \mathrm{m}^{-3}\left(0.17 \pm 0.15 \mathrm{ng} \mathrm{m}^{-3}\right.$ for sodium, $0.4 \pm 0.3 \mathrm{ng} \mathrm{m}^{-3}$ for sulfate, and 0 for MSA). The wind was occasionally blowing from the generator building of the Concordia station, disturbing measurements of atmospheric species like ozone (Legrand et al., 2016). Ozone measurements were also occasionally disturbed under very low wind speed conditions $\left(<2 \mathrm{~m} \mathrm{~s}^{-1}\right)$. The effect of such sporadic contamination of the station activities on the sulfate levels was here examined in the light of weekly denuder tube sampling of acidic gases done at the site, as detailed by Legrand et al. (2017) for $\mathrm{HCl}$ and $\mathrm{HNO}_{3}$. Indeed, the denuder tube sampling of acidic gases conducted at Concordia also documents $\mathrm{SO}_{2}$ by measuring sulfate on the extracts. After subtraction of a mean blank of sulfate of $1.5 \mathrm{ng} \mathrm{m}^{-3}$ (i.e., 0.3 pptv of $\mathrm{SO}_{2}$ ), the average mixing of $\mathrm{SO}_{2}$ collected from January 2013 to April 2016 (170 samples) is $0.7 \pm 0.6 \mathrm{pptv}$. It is therefore unlikely that the station activities had emitted enough $\mathrm{SO}_{2}$ to disturb the sulfate levels. 

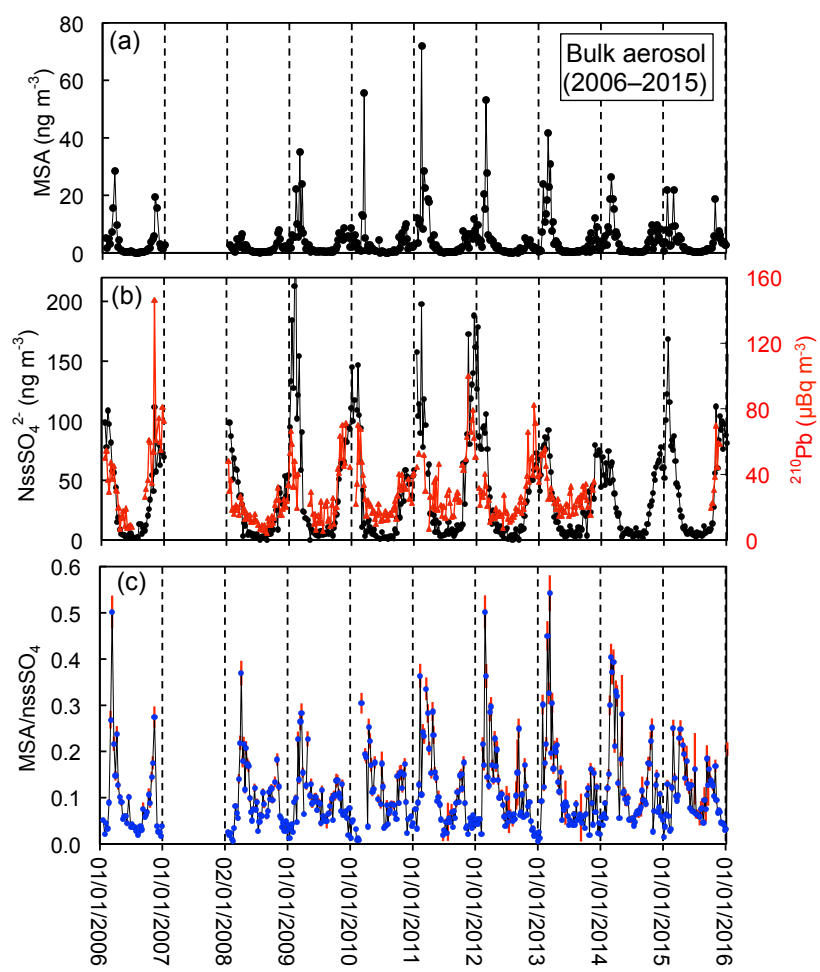

Figure 1. Weekly bulk aerosol concentrations of MSA (a), $\mathrm{nssSO}_{4}$ together with ${ }^{210} \mathrm{~Pb}$ activities (b), and the mass $\mathrm{MSA} / \mathrm{nssSO}_{4}$ ratio (c). Vertical bars refer to uncertainty in calculating the $\mathrm{MSA} / \mathrm{nssSO}_{4}$ ratio (Eq. 3). Nine values of the $\mathrm{MSA} / \mathrm{nssSO}_{4}$ ratio were off-scale: August $2008(1.1 \pm 0.8)$, October $2008(0.8 \pm 0.1)$, May $2009(0.7 \pm 0.3)$, March $2010(1.3 \pm 0.1,4.3 \pm 0.4$, and $1.7 \pm$ $0.1)$, June $2010(2.4 \pm 1.3)$, September $2010(-1.2 \pm 2.2)$, and July $2012(1.0 \pm 2.2)$.

As reported in Fig. 1, bulk aerosol chemical measurements were backed up by measurements of the ${ }^{210} \mathrm{~Pb}$ activities ( 310 samples) using $\gamma$-spectrometric quantification, as detailed by Wagenbach et al. (1988) and Elsässer et al. (2011). Due to the short half-life (53 days) of ${ }^{7} \mathrm{Be}$, its $\gamma$-spectrometric quantification was mainly done on September-January samples, just after their retrograde in Europe at the end of the austral summer season. In this way, ${ }^{7} \mathrm{Be}$ measurements were obtained on $48 \mathrm{HV}$ filters collected in summer 2006-2007, 2008-2009, 2009-2010, 2010-2011, and the end of 2015, permitting the documentation of the most important change of the ${ }^{7} \mathrm{Be} /{ }^{210} \mathrm{~Pb}$ activity ratio, as previously reported for the coastal Antarctic site of Neumayer (see Sect. 3.3.1). In addition to the non-destructive $\gamma$ spectrometry of ${ }^{210} \mathrm{~Pb}$ and ${ }^{7} \mathrm{Be},{ }^{10} \mathrm{Be}$ was chemically extracted from aliquot of filters collected in 2008 to allow quantification by accelerator mass spectrometry (AMS) at Dresden (DREAMS; Rugel et al., 2016). It is important to emphasize here that, whereas ${ }^{10} \mathrm{Be}$ is rather routinely measured in ice cores, its measurement in air samples is rather rare. The basic steps of chemical treatment are (1) the leaching of the filter with $10 \mathrm{~mL}$ very diluted $\mathrm{HCl}$ (ultrasonic bath for $5 \mathrm{~min}$, resting overnight) in the presence of $\sim 300 \mu \mathrm{g}$ of ${ }^{9} \mathrm{Be}$ carrier (Scharlau, $2 \% \mathrm{HCl}$, ${ }^{9} \mathrm{Be}$ concentration of $980.4 \pm 4.9 \mu \mathrm{g} \mathrm{g}^{-1}$ ); (2) filtration through PVDF filter (pore size of $0.45 \mu \mathrm{m}$ ); (3) precipitation of beryllium hydroxide by ammonia solution (25\%); (4) rinsing three times with dilute ammonia solution ( $\mathrm{pH} \mathrm{8-9);} \mathrm{(5)} \mathrm{drying} \mathrm{and} \mathrm{ig-}$ nition to $\mathrm{BeO}$ at $900^{\circ} \mathrm{C}$; and (6) mixing with $\mathrm{Nb}$ powder ( $1: 6$ by weight) and pressing into $\mathrm{Cu}$ cathodes. Every ninth sample was accompanied by a processing blank, which was treated identically as the filter samples. ${ }^{10} \mathrm{Be}$ data and subsequent ${ }^{10} \mathrm{Be} /{ }^{9} \mathrm{Be}$ AMS measurements result in ratios of $2 \times 10^{-13}$ to $1 \times 10^{-11}$ with total uncertainties from 2.0 to $4.4 \%$ (mean uncertainty $2.4 \%$ ).

The concentrations of nssSO 4 corresponding to HV samples were calculated as follows:

$\mathrm{nssSO}_{4}=\mathrm{SO}_{4}-k_{\mathrm{SO}_{4} / \mathrm{Na}} \mathrm{Na}$.

Examination of the size-segregated composition of aerosol present at Concordia indicates significant sulfate depletion relative to sodium with respect to the seawater composition from May to September (i.e., a $k_{\mathrm{SO}_{4} / \mathrm{Na}}$ value of $0.16 \pm 0.09$ instead of 0.25 in seawater) (Legrand et al., 2017), resulting from the presence of sea-salt aerosol at the site emitted from both open ocean and sea ice. This value of 0.16 was used in Eq. (1) to calculate the nssSO ${ }_{4}$ concentrations. From November to April, an absence of sulfate depletion relative to sodium in sea-salt aerosol is assumed and a $k_{\mathrm{SO}_{4} / \mathrm{Na}}$ value of 0.25 (i.e., the seawater reference value) was applied in Eq. (1).

The uncertainties in calculating the $\mathrm{nssSO}_{4}$ level are related to the accuracy of determinations of $\mathrm{SO}_{4}$ and $\mathrm{Na}$ as well as the uncertainties of the calculated value of $k_{\mathrm{SO}_{4} / \mathrm{Na}}$ :

$\Delta\left(\mathrm{nsSSO}_{4}\right)^{2}=$

$\left(k_{\mathrm{SO}_{4} / \mathrm{Na}} \Delta \mathrm{Na}\right)^{2}+\left(\mathrm{Na} \Delta k_{\mathrm{SO}_{4} / \mathrm{Na}}\right)^{2}+\left(\Delta \mathrm{SO}_{4}\right)^{2}$,

where $k_{\mathrm{SO}_{4} / \mathrm{Na}}$ is equal to 0.25 in summer (NovemberApril) and $0.16 \pm 0.09$ in winter (May-October), $\Delta \mathrm{SO}_{4}^{2}=$ $\left(0.05 \mathrm{SO}_{4}\right)^{2}+\sigma_{\text {blank }}^{2}$, and $\Delta \mathrm{Na}^{2}=(0.05 \mathrm{Na})^{2}+\sigma_{\text {blank }}^{2}$.

As discussed above, the $\mathrm{HV}$ blanks lead to a $\sigma_{\text {blank }}$ of $0.15 \mathrm{ng} \mathrm{m}^{-3}$ for $\mathrm{Na}$ and $0.3 \mathrm{ng} \mathrm{m}^{-3}$ for $\mathrm{SO}_{4}$.

Uncertainties in calculating the MSA to $\mathrm{nssSO}_{4}\left(\mathrm{R}_{\mathrm{MSA}}\right)$ ratio were estimated as follows:

$\Delta \mathrm{R}_{\mathrm{MSA}}^{2}=$

$\left(\Delta \mathrm{MSA} / \mathrm{nssSO}_{4}\right)^{2}+\left(\mathrm{MSA} \Delta \mathrm{nssSO}_{4} / \mathrm{nssSO}_{4}^{2}\right)^{2}$,

where $\triangle \mathrm{MSA}=0.05$ MSA.

On a total of $446 \mathrm{HV}$ filters, in nine cases we calculate $\mathrm{R}_{\mathrm{MSA}}$ values that are out of order, corresponding to low $\mathrm{nssSO}_{4}$ values $\left(<10 \mathrm{ng} \mathrm{m}^{-3}\right)$. These data (see the caption of Fig. 1) were not considered when calculating the monthly $\mathrm{R}_{\text {MSA }}$ means reported in Fig. 2. 

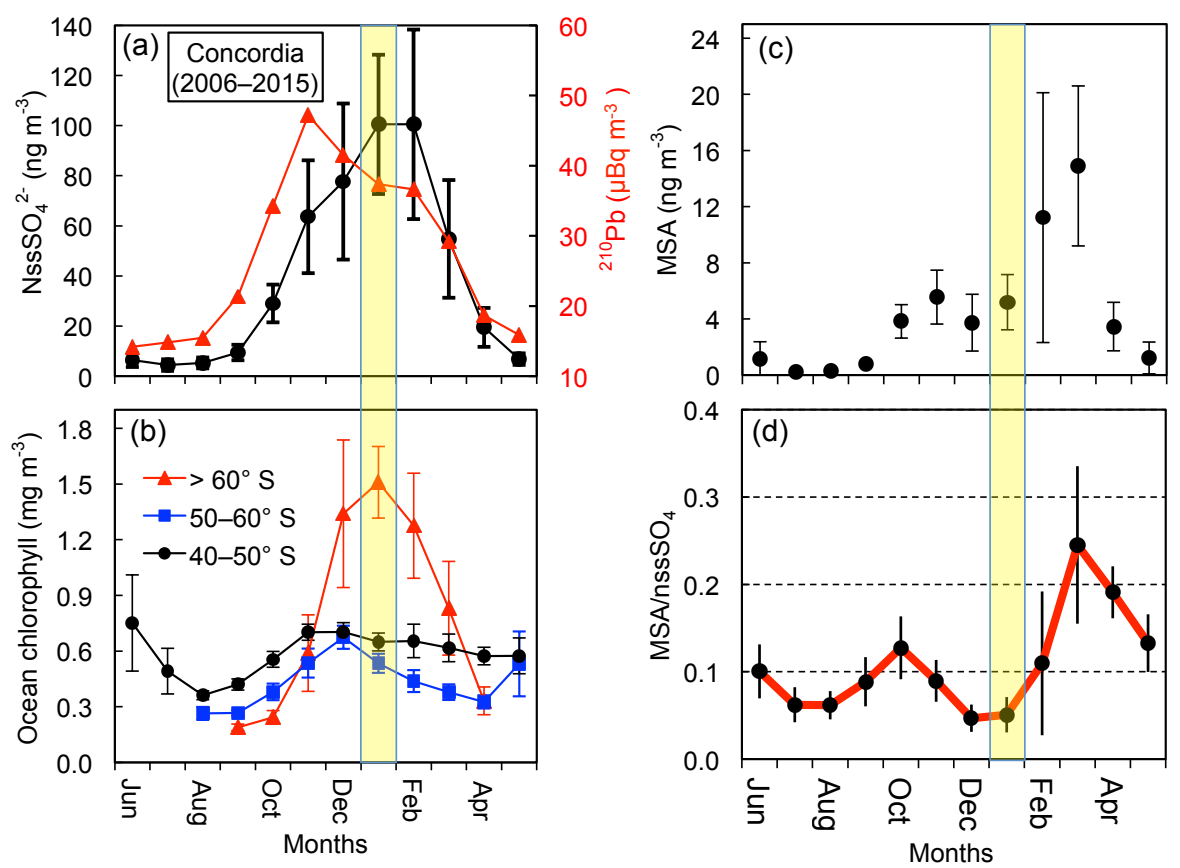

Figure 2. Monthly mean concentration of nssSO 4 along with ${ }^{210} \mathrm{~Pb}$ level (a), MSA (c), and MSA / nssSO 4 ratio (d) in bulk aerosol collected at Concordia from January 2006 to January 2016. (b) Monthly mean chlorophyll concentration in the Southern Ocean (2002-2011) (MODISAqua satellite data as reprocessed by Johnson et al., 2013). Vertical bars denote year-to-year variability.

In addition, the size-segregated aerosol composition was investigated by doing 105 samplings between March 2006 and January 2012 by using a small deposit area impactor, equipped with a $20 \mu \mathrm{m}$ cutoff diameter inlet (Legrand et al., 2017). Applying a sampling interval of 2 weeks, eight runs per year were done in 2006 and 2007 and a more continuous sampling (25 runs) from 2009 to 2012. The blank values of the deposit remain well below $1 \mathrm{ng} \mathrm{m}^{-3}\left(0.17 \pm 0.12 \mathrm{ng} \mathrm{m}^{-3}\right.$ for sodium, $0.08 \pm 0.06 \mathrm{ng} \mathrm{m}^{-3}$ for sulfate, and 0 for MSA). All data were blank corrected. The $\mathrm{nssSO}_{4}$ and $\mathrm{R}_{\mathrm{MSA}}$ values were calculated by applying in Eq. (1) a $k_{\mathrm{SO}_{4} / \mathrm{Na}}$ value of 0.25 in summer (November-April). For winter sampling (from May to October), the calculations were done for each impactor run by using the individual $k_{\mathrm{SO}_{4}} / \mathrm{Na}$ value derived from the corresponding impactor run, as detailed in Legrand et al. (2017). Briefly, the $k_{\mathrm{SO}_{4} / \mathrm{Na}}$ values are derived by examining the levels of sulfate and sodium present on the stages where most of sea-salt aerosol was collected $(0.5-2.0 \mu \mathrm{m}$ diameter) and having corrected sulfate from its small (but significant) biogenic sulfate contribution, as estimated from MSA levels.

Over the 2009 to 2011 years, aerosol was sampled on both bulk filter and impactor. A good agreement between the two data sets is found for sulfate as well as MSA (not shown). For sulfate, the relationship between the sum of concentrations observed on the impactor ([ $\left.\left.\mathrm{SO}_{4}\right]_{\text {impactor }}\right)$ and the concentration observed on the bulk filter $\left(\left[\mathrm{SO}_{4}\right]_{\text {bulk }}\right)$ is $\left[\mathrm{SO}_{4}\right]_{\text {impactor }}=$ $0.91( \pm 0.08) \times\left[\mathrm{SO}_{4}\right]_{\text {bulk }}$ with $R^{2}=0.75$. For MSA the rela- tionship is $[\mathrm{MSA}]_{\text {impactor }}=0.75( \pm 0.06) \times[\mathrm{MSA}]_{\text {bulk }}$ with $R^{2}=0.8$. The slight difference between the two data sets is likely due to differences (up to a few days) in the sampling time intervals.

\section{Results and discussions}

The aerosol record at Concordia now covers a decade. The long-term sulfate and MSA trends were examined by calculating the regression line slopes through annual and monthly mean values. No significant trend can be observed. For instance, a very weak annual increasing rate of $1.9 \pm 5.6 \mathrm{ng} \mathrm{m}^{-3} \mathrm{yr}^{-1}$ is calculated for sulfate in summer, but the regression line slope was found to be not statistically different from zero at the $P>95 \%$ confidence level. As shown in Fig. 1, both nssSO $\mathrm{S}_{4}$ and ${ }^{210} \mathrm{~Pb}$ levels in bulk aerosol collected at Concordia steadily increase from September to November and decrease from February to April. In Antarctica, the seasonal change of ${ }^{210} \mathrm{~Pb}$, which is useful to trace the long-range transport of continental submicron aerosol is characterized by summer maximum mainly driven by (1) strong inversion layer in winter particularly at inland sites and (2) seasonal change in the efficiency of the meridional long-range transport (Elsässer et al., 2011). At Concordia, the seasonal ${ }^{210} \mathrm{~Pb}$ amplitude (a factor of 3 from May-August to November-February) is weaker than that of $\mathrm{nssSO}_{4}$ (more than a factor of 10, Fig. 2). Since ${ }^{210} \mathrm{~Pb}$ and $\mathrm{nssSO}_{4}$ are both 
Table 1. $\mathrm{MSA}_{\mathrm{nssSO}}^{2-}$, and $\mathrm{MSA} / \mathrm{nssSO}_{4}$ ratios $\left(\mathrm{R}_{\mathrm{MSA}}\right.$ ) in winter (June-September), November, and January at Concordia (DC, 20062015) and the coastal site of Neumayer (NM, 1983-1995) and Dumont d'Urville (DDU, 1991-1996).

\begin{tabular}{|c|c|c|c|c|}
\hline Sites/periods & $\operatorname{MSA}\left(\operatorname{ng~m}^{-3}\right)$ & $\mathrm{nssSO}_{4}\left(\mathrm{ng} \mathrm{m}^{-3}\right)$ & $\mathrm{R}_{\mathrm{MSA}}$ & References \\
\hline DC (Jun-Sep) & $0.6 \pm 0.4$ & $6.4 \pm 2.2$ & $0.08 \pm 0.02$ & This work \\
\hline NM (Jun-Sep) & $3.3 \pm 1.9$ & $40 \pm 11$ & $0.08 \pm 0.02$ & $\begin{array}{l}\text { Minikin et al. (1998) } \\
\text { Legrand and Pasteur (1998) }\end{array}$ \\
\hline DDU (Jun-Sep) & $2.4 \pm 1.2$ & $27 \pm 8$ & $0.09 \pm 0.02$ & $\begin{array}{l}\text { Minikin et al. (1998) } \\
\text { Jourdain and Legrand (2002) }\end{array}$ \\
\hline DC (Nov) & $5.6 \pm 1.9$ & $64 \pm 22$ & $0.09 \pm 0.02$ & This work \\
\hline NM (Nov) & $19.6 \pm 6.1$ & $152 \pm 32$ & $0.13 \pm 0.03$ & $\begin{array}{l}\text { Minikin et al. (1998) } \\
\text { Legrand and Pasteur (1998) }\end{array}$ \\
\hline DDU (Nov) & $17 \pm 2.5$ & $151 \pm 33$ & $0.11 \pm 0.04^{*}$ & $\begin{array}{l}\text { Minikin et al. (1998) } \\
\text { Jourdain and Legrand (2002) }\end{array}$ \\
\hline DC (Jan) & $5.2 \pm 2.0$ & $100 \pm 28$ & $0.05 \pm 0.02$ & This work \\
\hline NM (Jan) & $154 \pm 77$ & $380 \pm 130$ & $0.41 \pm 0.13$ & $\begin{array}{l}\text { Minikin et al. (1998) } \\
\text { Legrand and Pasteur (1998) }\end{array}$ \\
\hline DDU (Jan) & $60 \pm 23$ & $280 \pm 79$ & $0.21 \pm 0.05^{*}$ & $\begin{array}{l}\text { Minikin et al. (1998) } \\
\text { Jourdain and Legrand (2002) }\end{array}$ \\
\hline
\end{tabular}

* The values are slightly higher than those reported by Legrand and Pasteur (1998) ( $0.08 \pm 0.02$ in November and $0.16 \pm 0.01$ in January) since, following Jourdain and Legrand (2002), they were calculated after having subtracted the contribution of ornithogenic soils to the sodium and sulfate levels.

present in the atmosphere as submicron aerosol, this difference cannot be attributed to different atmospheric lifetime. Instead, this difference implies a strong seasonal change of sulfur emissions, particularly from September to November and February to April. That is supported by satellite observations showing that concentrations of chlorophyll at high latitudes in the southern surface ocean are increased and decreased at spring and fall equinoxes, respectively (Fig. 2).

In the following we discuss the respective abundance of the two sulfur species at Concordia, their seasonal cycle, and variability over the nine year-round records (Sect. 3.1). We then focus discussions on the striking drop of the MSA to $\mathrm{nssSO}_{4}$ ratio observed during mid-summer over inland Antarctica (Sect. 3.2). Finally, in Sect. 3.3 we examine the importance of non-biogenic sources of sulfate for inland Antarctica over the course of the year.

\subsection{Seasonal cycle of $\mathrm{MSA}$ and $\mathrm{nsSSO}_{4}$ levels at Concordia}

In winter (June-September), the levels of MSA and $\mathrm{nssSO}_{4}$ at Concordia remain as low as $0.6 \pm 0.4$ and $6.4 \pm 2.2 \mathrm{ng} \mathrm{m}^{-3}$, respectively (Table 1 ). The relative contribution of marine biogenic vs. non-biogenic sources to the sulfate budget over the Antarctic plateau in winter will be discussed in Sect. 3.3. From winter to November, MSA and $\mathrm{nssSO}_{4}$ levels exhibit a similar increase by a factor of 9 to 10 (Table 1). This increase is larger than the ones seen at coastal sites (a factor of 6 to 7 for MSA and close to a factor of 5 for $\mathrm{nsSSO}_{4}$; Table 1). The increase of $\mathrm{MSA}_{\text {and }} \mathrm{nssSO}_{4}$ from September to November at the coast was attributed by Minikin et al. (1998) to the recovery of the marine biota in the
Southern Ocean. The larger increase of the two sulfur species from winter to spring at Concordia compared to coastal sites is likely related to weakening of the inversion layer at Concordia at the end of winter that also contributes to the increase there. As seen in Table 1, both at coastal sites and Concordia the $R_{M S A}$ ratio remains close to 0.08 in winter. Such a low value of $\mathrm{R}_{\mathrm{MSA}}$ is discussed in terms of source region of biogenic sulfur in Sect. 3.3.2.

The maximum of $\mathrm{nssSO}_{4}$ in January seen in multipleyear records available at the coastal sites of NM and DDU (Fig. 3) is also observed in the multiple-year $\mathrm{nssSO}_{4}$ record at Concordia (Fig. 2). As seen in Table 1, the $\mathrm{nssSO}_{4}$ levels are coastal sites are enhanced by around a factor of 2 from November to January. At Concordia, the $\mathrm{nssSO}_{4}$ levels are consistently increasing from $63.6 \pm 22.5 \mathrm{ng} \mathrm{m}^{-3}$ in November to $100.4 \pm 25.3 \mathrm{ng} \mathrm{m}^{-3}$ in January. A larger increase of MSA compared to the nssSO 4 is observed from November to January at the coast (more than a factor of 3; Table 1) leading to a large increase of $\mathrm{R}_{\mathrm{MSA}}$. Given the latitudinal dependence of $\mathrm{R}_{\mathrm{MSA}}$ characterized by high values at very high latitudes $\left(>60^{\circ} \mathrm{S}\right)$, such a difference in the recovery of MSA and $\mathrm{nsSSO}_{4}$ in January is expected since the activity of marine biota at latitudes higher than $60^{\circ} \mathrm{S}$ peaks at that time (Fig. 2). Note the lower value of $\mathrm{R}_{\mathrm{MSA}}$ in January at DDU compared to NM (Table 1) that will be discussed in Sect. 4.

At Concordia, a quite different picture emerges for MSA with levels peaking before and after sulfate (in November and March; Fig. 2). Even more dramatic is the difference of $R_{M S A}$ between Concordia and coastal sites with values dropping at 0.05 in January at Concordia (Fig. 2) versus around 0.2 at DDU and 0.4 at NM (Fig. 3). Given the relative abundance of MSA with respect to $\mathrm{nssSO}_{4}$ at the coast, with a mean level 

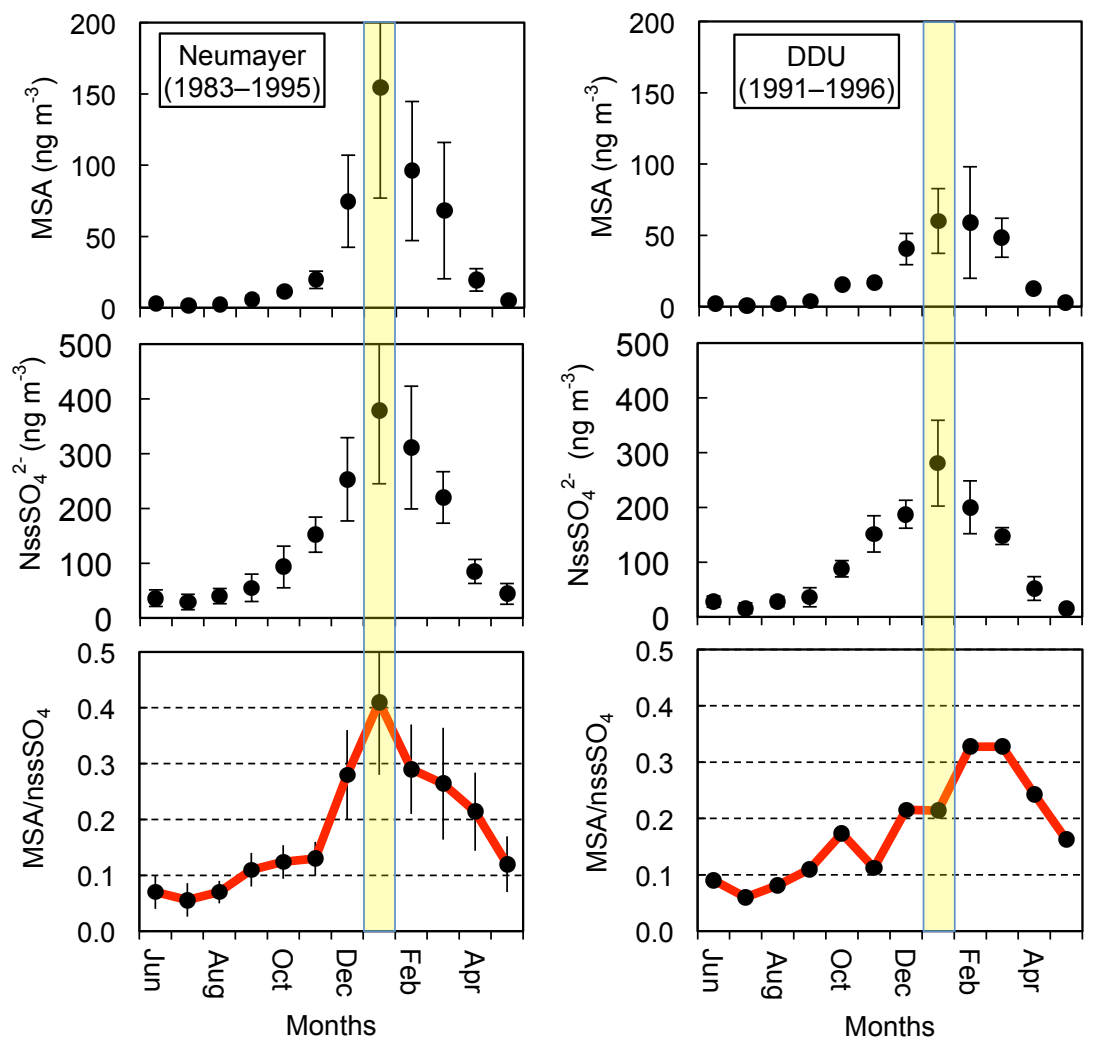

Figure 3. Monthly mean values of $\mathrm{MSA} \mathrm{nssSO}_{4}$, and $\mathrm{MSA} / \mathrm{nssSO}_{4}$ ratio, in bulk aerosol collected at Neumayer (1983-1995) (left) and DDU (1991-1996) (right). Adapted from Minikin et al. (1998) and Legrand and Pasteur (1998). Vertical bars denote year-to-year variability.

Table 2. $\mathrm{MSA} / \mathrm{nssSO}_{4}$ ratios $\left(\mathrm{R}_{\mathrm{MSA}}\right.$ ) observed at inland Antarctic sites in mid-summer and in February/March (if available).

\begin{tabular}{|c|c|c|c|}
\hline Site & $\mathrm{R}_{\mathrm{MSA}}$ & Month/year & References \\
\hline \multirow[t]{3}{*}{ South Pole } & 0.063 & Nov-Dec 2003 & Arimoto et al. (2008) \\
\hline & 0.08 & Nov 2000/Jan 2001 & Arimoto et al. (2004) \\
\hline & 0.059 & Dec 1998/Jan 1999 & Arimoto et al. (2001) \\
\hline \multirow{10}{*}{$\begin{array}{l}\text { Concordia } \\
\left(75^{\circ} \mathrm{S}, 123^{\circ} \mathrm{E}\right)\end{array}$} & 0.094 & Jan 2000 & Piel et al. (2006) \\
\hline & 0.052 & Dec 2000/Jan 2001 & \\
\hline & 0.15 & Dec 2001/Jan 2002 & \\
\hline & 0.028 & Dec 2000/Jan 2001 & Udisti et al. ( 2004) \\
\hline & $\sim 0.06$ & Dec 2006 & Becagli et al. (2012) \\
\hline & $\sim 0.25$ & Feb 2006 & \\
\hline & $\sim 0.04$ & Dec 2006 & Preunkert et al. (2008) \\
\hline & $\sim 0.40$ & Mar 2006 & \\
\hline & $0.05 \pm 0.03$ & Jan 2006, 2008-2015 & This work \\
\hline & $0.25 \pm 0.09$ & March 2006, 2008-2015 & \\
\hline \multirow{2}{*}{$\begin{array}{l}\text { EDML } \\
\left(75^{\circ} \mathrm{S}, 0^{\circ} \mathrm{E}\right)\end{array}$} & $0.15 \pm 0.05$ & Jan/Feb 2000-2002 & Piel et al. (2006) \\
\hline & 0.33 & March 2003-2005 & Weller and Wagenbach (2007) \\
\hline
\end{tabular}

of $100 \mathrm{ng} \mathrm{m}^{-3}$ of $\mathrm{nssSO}_{4}$ at Concordia in January we would expect between 21 and $41 \mathrm{ng} \mathrm{m}^{-3}$ of MSA at that time (i.e., 4 to 8 times higher than the mean observed level of $5.2 \mathrm{ng} \mathrm{m}^{-3}$; Table 1).
A few previous studies already pointed out the occurrence of $\mathrm{R}_{\mathrm{MSA}}$ as low as 0.1 or less at inland Antarctic sites in mid-summer. As seen in Table 2, most of observations were restricted to a few weeks in December and/or January except the one conducted at Kohnen (located at 2890 m a.s.1. 

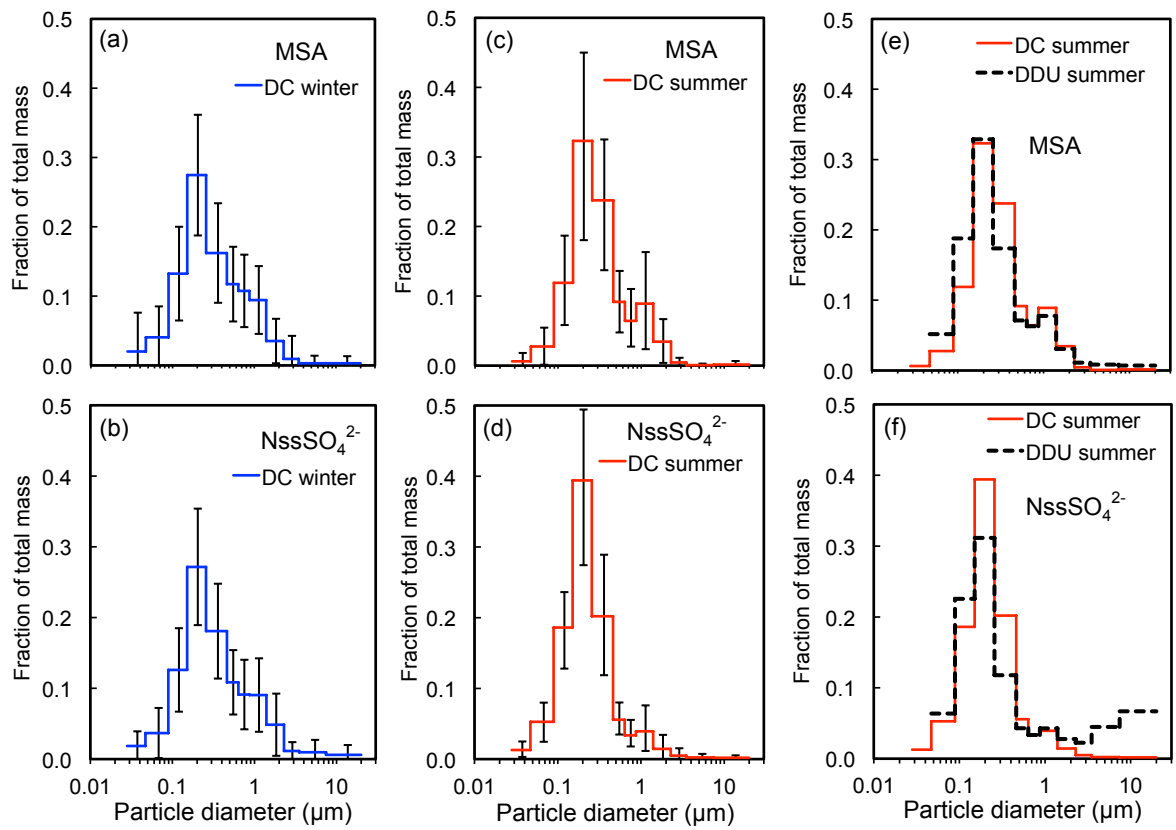

Figure 4. Mean size-segregated mass composition of sulfur aerosol (MSA and non-sea-salt sulfate) at Concordia in winter (a, b) and summer (c, d), at Concordia and DDU in summer (e, f). Vertical bars reported in panels (a)-(d) denote sample-to-sample variability. The presence of very large nssSO 4 particles at DDU in summer (dashed black line in panel f) is due to sulfate from ornithogenic soils present at the site (Jourdain and Legrand, 2002). Note that at DDU the impactor was run using only 11 stages, missing the smallest particles.

in Dronning Maud Land) by Weller and Wagenbach (2007) where a composite annual cycle based on discontinuous sampling done over 2.5 years was obtained. In addition, Preunkert et al. (2008) and Becagli et al. (2012) reported continuous samplings done at Concordia over the year 2006. However, none of them examined in detail the change of $\mathrm{R}_{\mathrm{MSA}}$ over the course of summer (from spring to summer and fall) and its variability from year to year.

\subsection{Causes of the weak abundance of MSA compared to $\mathrm{nsSSO}_{4}$ in mid-summer}

\subsubsection{Previous invoked causes of low $\mathbf{R}_{\text {MSA }}$ in summer at inland Antarctica}

Several aspects have to be considered in discussing causes of the surprising decrease of $\mathrm{R}_{\mathrm{MSA}}$ in December/January compared to values in October and March at Concordia compared to what is observed at the coast. They mainly include segregation between MSA and sulfate during transport towards DC via either formation or deposition of the two species. In addition, as proposed to explain the loss of MSA from the snowpack, we cannot exclude the possibility of an evaporative loss from aerosol.

Here we may first invoke a different size distribution of nssSO $_{4}$ and MSA leading to a change of their respective abundance during transport between the ocean and central Antarctica. Indeed, several studies (Rankin and Wolff, 2003; Kerminen et al., 2000) pointed out an enrichment of MSA with respect to $\mathrm{nssSO}_{4}$ in supermicron compared to submicron particles at coastal Antarctic sites in summer. In this way, the decrease of $\mathrm{R}_{\mathrm{MSA}}$ at Concordia in December and January could be explained by (1) a larger abundance of MSA with respect to nssSO ${ }_{4}$ in large than in small particles at the coast and (2) a transport of marine air mass between the coast and Concordia becoming less efficient in December and January compared to October and March. An alternative possibility involves a selective formation of sulfate with respect to MSA under mid-summer conditions in inland Antarctica. As discussed by Davis et al. (1998), the $\mathrm{R}_{\mathrm{MSA}}$ ratio in Antarctica is strongly influenced by the respective importance of liquid- and gas-phase sulfur chemistry. Briefly, the $\mathrm{OH}$ oxidation of DMS produces $\mathrm{SO}_{2}$ (abstraction pathway), DMSO, and $\mathrm{SO}_{2}$ (addition pathway). DMSO is further oxidized by $\mathrm{OH}$ either in the gas phase or in the aqueous or aerosol phase. Legrand et al. (2001) reported that the heterogeneous DMSO oxidation efficiently produces MSA in summer at the coast. The efficiency of this heterogeneous process has been confirmed by kinetic studies (Bardouki et al., 2002). Therefore, due to a larger presence of aerosol, it is expected that the oxidation of DMSO would produce much more MSA in the atmospheric boundary layer compared to the buffer layer above. That was supported by field observations made by Davis et al. (1998) at the Palmer site showing a rapid increase of DMSO when vertical downward transport brought buffer layer air mass within the boundary layer. These observations imply a longer lifetime of DMSO in the buffer 
layer than in the boundary layer, following a strong weakening of the heterogeneous reaction of DMSO caused by a far lower aerosol surface (and liquid water) available there. From that, Preunkert et al. (2008) proposed that the weakening of marine advection in December-January compared to March associated with an ongoing oxidation of $\mathrm{SO}_{2}$ into sulfate in the buffer layer, where the heterogeneous chemistry of DMSO is very limited, would account for the drop of $\mathrm{R}_{\mathrm{MSA}}$ observed in mid-summer at Concordia. Note, however, that this hypothesis was based on observations that were limited to 1 year.

\subsubsection{Size-segregated composition of sulfur aerosol at Concordia in summer}

The previously mentioned enrichment of MSA with respect to $\mathrm{nsSSO}_{4}$ seen in supermicron compared to submicron particles at the coast in summer is also observed at DDU, a coastal site located in margin regions facing the Indian and Pacific oceanic sectors from which most of the marine air mass reaching Concordia comes. As shown in Fig. 4, the second supermicron mode of MSA in aerosol at DDU remains centered around $1-2 \mu \mathrm{m}$ and differs from the coarse sea-salt aerosol mode observed at $6-8 \mu \mathrm{m}$ by Jourdain and Legrand (2001, 2002). The contribution of the second mode to the total MSA mass remains rather weak (less than 18\%). At Concordia in summer, the size distribution is very similar to the one observed at DDU with no significant decreasing contribution of the supermicron particles to total MSA mass between the two sites (Fig. 4). Furthermore, as seen in Fig. 5, the size distributions of the two sulfur species typically observed at Concordia indicate no significant decreasing contribution of the supermicron mode to the total MSA mass in summer compared to other seasons (16\% in winter, $18 \%$ in spring and summer, and $10 \%$ in fall). That suggests an absence of selective deposition of MSA during transport between the coast and the inland Antarctic plateau in midsummer. The weak contribution of supermicron particles to the total MSA mass, as observed at the coast, likely limits the segregation between MSA and $\mathrm{nssSO}_{4}$ during the transport between ocean and Concordia. It is also interesting to notice that the dominant presence of MSA in submicron sulfuric acid particles does not confirm the statement generally presented in previous studies that, after its formation in the gas phase, in contrast to sulfuric acid, MSA is more easily incorporated in larger, less acidic particles (Jefferson et al., 1998). Since DMSO is soluble in acidic solution, we may in fact expect that its solubilization in hydrated acidic aerosol followed by a rapid oxidation into MSA explains the presence of this latter in sulfuric acid particles.

Figure 6 shows that the large drop of $\mathrm{R}_{\mathrm{MSA}}$ observed on bulk aerosol in summer (Fig. 2, see also Fig. 8 in Sect. 3.2.3.) is consistently revealed by impactor data (open triangles in Fig. 6). It also shows a far more pronounced decrease of $\mathrm{R}_{\mathrm{MSA}}$ in submicron than micron particles. An example of
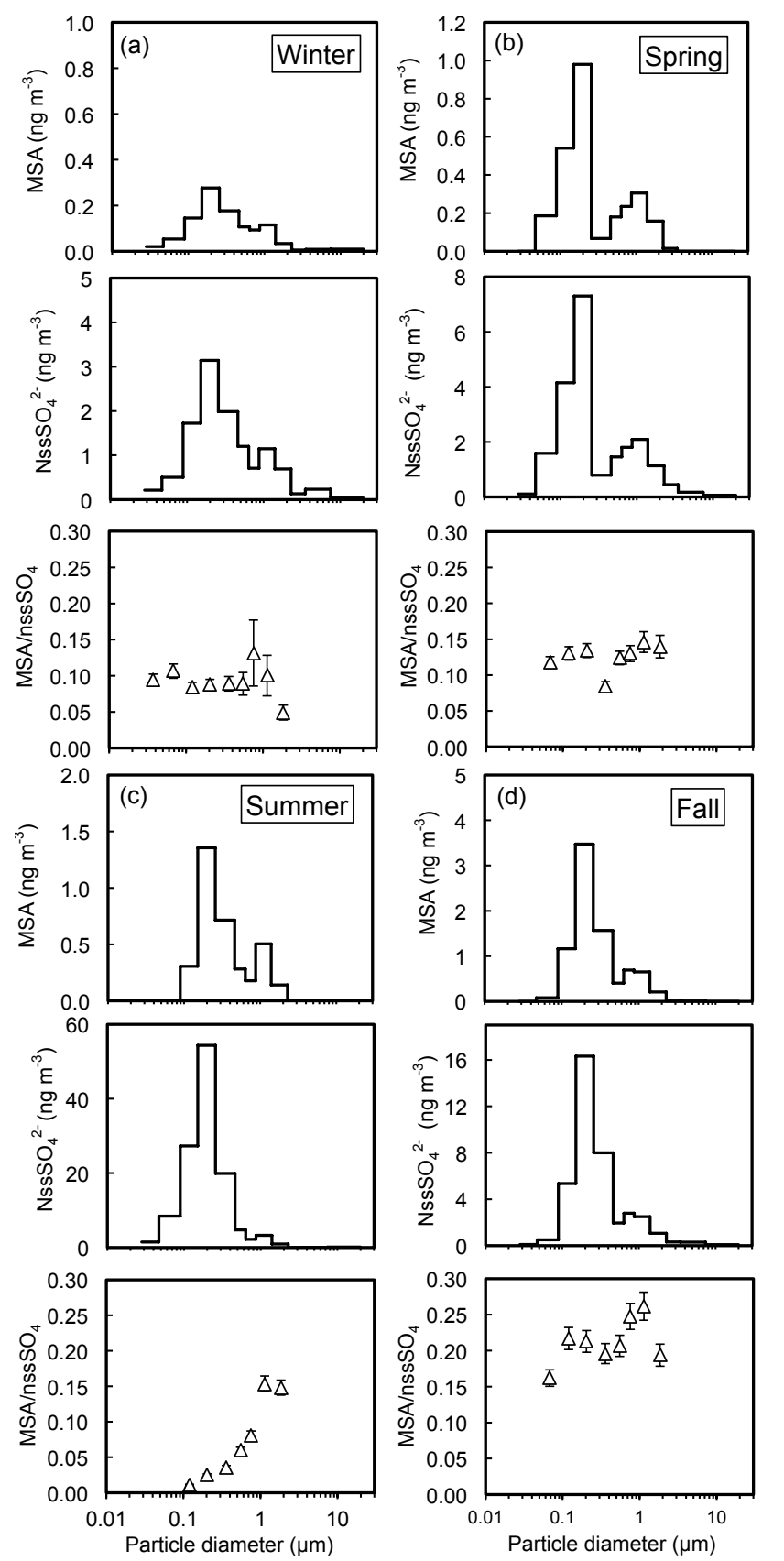

Figure 5. Size-segregated composition of sulfur aerosol (MSA, non-sea-salt sulfate, and MSA / nssSO 4 ) at Concordia in winter (a 14-28 August 2009), spring (b 9-22 October 2010), summer (c 922 January 2010), and fall (d 28 March-11 April 2011).

this strong depletion of MSA relative to $\mathrm{nsSSO}_{4}$ in submicron compared to micron particles in summer is seen in Fig. 5c. As a consequence, since the contribution of submicron particles dominates the total mass of MSA, the drop $\mathrm{R}_{\mathrm{MSA}}$ values in mid-summer at Concordia is mainly due to a drop of $\mathrm{R}_{\mathrm{MSA}}$ in submicron particles. A drop of $\mathrm{R}_{\mathrm{MSA}}$ may result from an increase of sulfate and/or a drop of MSA. Impactor data corre- 


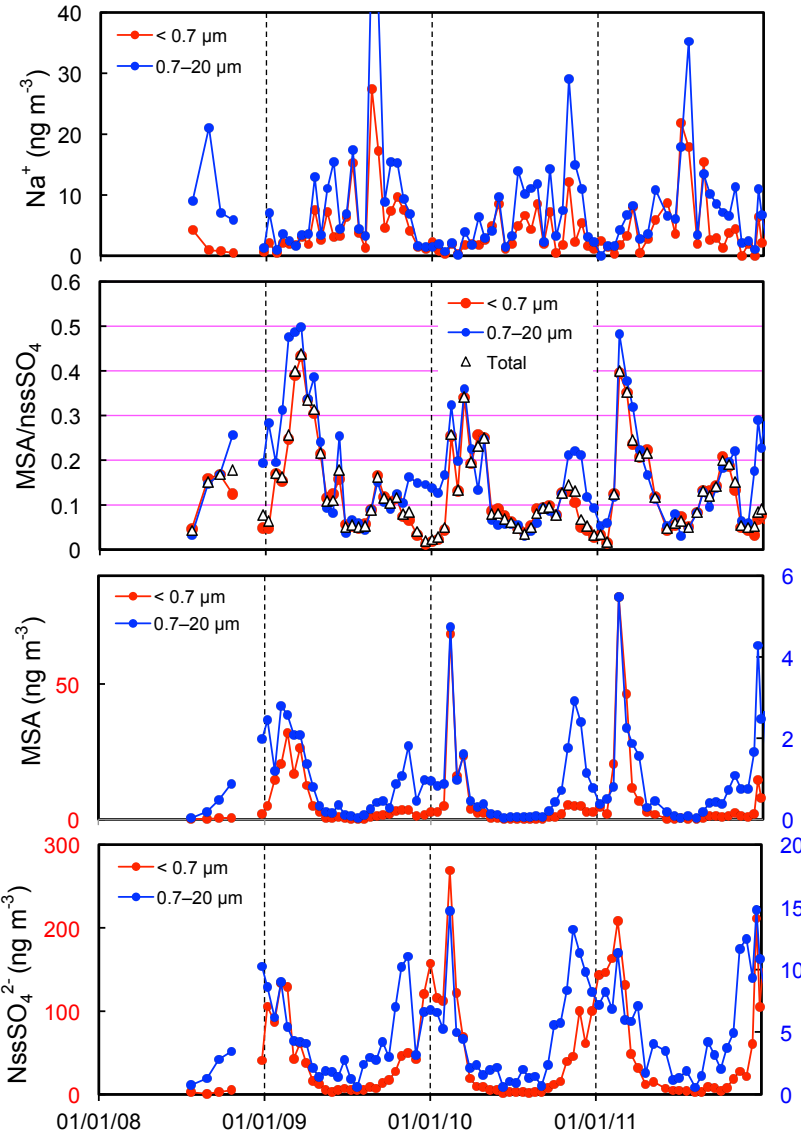

Figure 6. Year-round records of the chemical composition of aerosol collected from 2008 to 2011 at Concordia on the 12-stage impactor, distinguishing between small (the last six stages, i.e., $0.08-0.7 \mu \mathrm{m}$ diameter) and large (the first six stages, i.e., $0.7-20 \mu \mathrm{m}$ diameter) particles. From top to bottom: sodium, $\mathrm{MSA}_{\mathrm{nssSO}}$ ratio, MSA, and nssSO 4 . For the $\mathrm{MSA}_{/} \mathrm{nssSO}_{4}$ ratio, we also report values corresponding to the total mass of collected aerosol (open triangles). Note the different scales used for small (left scales) and large (right scales) particles for MSA and $\mathrm{nssSO}_{4}$.

sponding to the March-November time period (Fig. 7a and b) show that $\mathrm{R}_{\mathrm{MSA}}$ is very poorly related to the $\mathrm{nsSSO}_{4}$ content ( $R^{2}$ of 0.01 and 0.06 for submicron and micron particles, respectively). Conversely, the higher is the MSA content the higher is $\mathrm{R}_{\mathrm{MSA}}$ ( $R^{2}$ of 0.55 and 0.47 for submicron and micron particles, respectively). In fact, as seen in Fig. 7c and d, when distinguishing samples with a high and low nssSO content (higher and lower than $100 \mathrm{ng} \mathrm{m}^{-3}$ ), a strong relationship is found between MSA and $\mathrm{R}_{\mathrm{MSA}}$. Note that most of samples containing less than $100 \mathrm{ng} \mathrm{m}^{-3}$ of $\mathrm{nssSO}_{4}$ correspond to the November-December period, whereas those containing more than $100 \mathrm{ng} \mathrm{m}^{-3}$ of $\mathrm{nssSO}_{4}$ to the JanuaryMarch period. In this way, the drop of $\mathrm{R}_{\mathrm{MSA}}$ from November to December and from February-March to January is examined separately. In both cases, the $\mathrm{R}_{\mathrm{MSA}}$ drop is mainly due to a decrease of MSA. For instance, in submicron particles
$R^{2}$ equal to 0.86 is calculated for samples containing less than $100 \mathrm{ng} \mathrm{m}^{-3}$ of $\mathrm{nssSO}_{4}$ ( 0.84 for those having more than $100 \mathrm{ng} \mathrm{m}^{-3}$ of $\left.\mathrm{nssSO}_{4}\right)$. The same is seen for supermicron particles ( $\mathrm{R}^{2}$ equal to 0.89 and 0.83 for samples containing less and more than $100 \mathrm{ng} \mathrm{m}^{-3}$ of $\mathrm{nssSO}_{4}$, respectively).

\subsubsection{Chemical signature of air mass experienced a summer drop of MSA concentrations}

The year-round record of $\mathrm{R}_{\mathrm{MSA}}$ (HV filter data) was examined at the light of different parameters related to the history of air mass present during sampling at Concordia (Fig. 8). This was done by using 10-day backward trajectory as well as chemical characteristics (i.e., sodium, $\mathrm{MSA}, \mathrm{nssSO}_{4}$, and ozone) and air temperature at the site. We restrict the discussion to the last 5 years, for which the chemical records are the most continuous (Fig. 8). Sodium is here used to evaluate the importance of marine advection from spring to fall and its interannual variability. As discussed by Legrand et al. (2009), ozone at Concordia exhibits a seasonal cycle characterized by a maximum in July followed by a decrease until October and the occurrence of a secondary maximum in NovemberJanuary (Legrand et al., 2009), similar to what is observed at the South Pole (Crawford et al., 2001). Whereas it is expected that such very remote regions experience winter accumulation of $\mathrm{O}_{3}$ transported from other regions followed by photochemical destruction in spring and summer, the occurrence of a secondary maximum in November-January is surprising. That was attributed to a photochemical ozone production induced by the high $\mathrm{NO}_{x}$ levels generated by the photo-denitrification of the Antarctic snowpack (Davis et al., 2001).

The sodium record reported in Fig. $8 \mathrm{f}$ does not support the assumption that the drop of $\mathrm{R}_{\mathrm{MSA}}$ values coincides with a weakening of marine air advection. Indeed, whereas there are in general much more sodium (late October-early November) just before the drop of $\mathrm{R}_{\mathrm{MSA}}$ (see the grey areas in Fig. 8c), the recovery of high $\mathrm{R}_{\mathrm{MSA}}$ values in fall (FebruaryMarch) is never accompanied by a recovery of sodium levels. For example, $\mathrm{R}_{\mathrm{MSA}}$ jumped from $<0.10$ mid-February 2014 to 0.40 at the end of February 2014, whereas the sodium levels remained over the whole period between 1 and $3 \mathrm{ng} \mathrm{m}^{-3}$. Consistently with what is observed on impactor (Fig. 7), HV data indicate that the drop of $\mathrm{R}_{\mathrm{MSA}}$ in mid-summer at Concordia is related to a decrease of MSA rather than an increase of $\mathrm{nsSSO}_{4}$ levels (Fig. 8d). The lack of a recovery of marine air advection in fall and the fact that low $\mathrm{R}_{\mathrm{MSA}}$ values are more related to low MSA rather than high nssSO ${ }_{4}$ levels do not support the preceding assumption of a chemistry favoring sulfate during transport in mid-summer as resulting from a weakening of marine advection and a chemistry of DMSO promoting formation of sulfate in the absence of heterogeneous chemistry. Note also that the temperature record (Fig. 8e) does not support the possibility of a drop of MSA caused by evaporative loss from aerosol. 

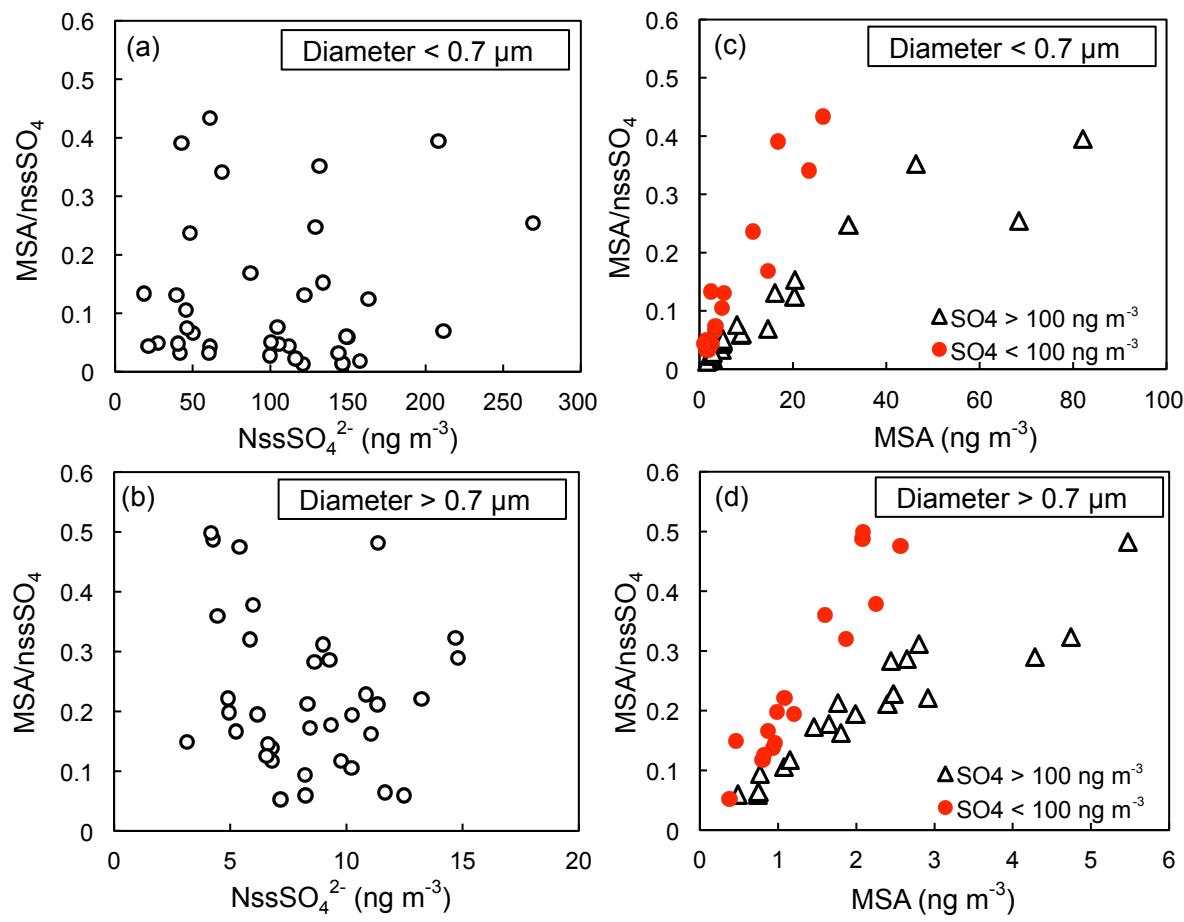

Figure 7. Relationship between the $\mathrm{MSA} / \mathrm{nssSO}_{4}$ ratio and the $\mathrm{nsSSO}_{4}$ level in small (a) and large (b) particles collected on the 12-stage impactor in summer (from November to March). Panels (c) and (d) are the same for the relationship between the $\mathrm{MSA}_{/} \mathrm{nssSO}_{4}$ ratio and the MSA level, distinguishing samples containing more (open triangles) or less (red points) than $100 \mathrm{ng} \mathrm{m}^{-3} \mathrm{of} \mathrm{nssSO}_{4}$.

The fact that the drop of $\mathrm{R}_{\mathrm{MSA}}$ values in mid-summer at Concordia is mainly due to the disappearance of MSA in the fine aerosol and not to an increase of sulfate permits us to reject the assumptions of (1) a selective deposition of MSA with respect to sulfate or (2) a preferential production of sulfate with respect to MSA during transport between the coast and the inland Antarctic plateau. As seen in Fig. 8, the only significant change that coincides fairly well with the drop of $R_{\mathrm{MSA}}$ in mid-summer is the occurrence of the secondary maximum of ozone mixing ratio that is attributed to a local photochemical activity driven by $\mathrm{NO}_{x}$ emissions from the snowpack of the Antarctic plateau. To illustrate the timing and the amplitude of the photochemical ozone production we have reported in Fig. 8a the de-seasonalized ozone record. It is seen that the sudden appearance of low $R_{M S A}$ values that generally occurred at the beginning of November and ended in February (see the grey areas in Fig. 8) coincides with the periods over which the excess of ozone related to the strong photochemical activity took place. The link between low $\mathrm{R}_{\mathrm{MSA}}$ values and high photochemical activity is also seen in the interannual variability, with particularly low $\mathrm{R}_{\mathrm{MSA}}$ values in November-December 2011 and $2012(\sim 0.03)$ compared to November-December 2013 and 2014 (0.08) corresponding to larger excess ozone (10.5 ppbv in NovemberDecember 2011 and 2012 versus $8.0 \mathrm{ppbv}$ in NovemberDecember 2013 and 2014). As discussed by Legrand et al. (2016), the more time spent by the air mass above $3200 \mathrm{~m}$ elevation prior to its arrival at Concordia, the higher the ozone mixing ratio was. That can be seen in Fig. $8 \mathrm{~b}$ when comparing the fraction of time spent by the air mass above $3200 \mathrm{~m}$ a.s.l. in November-December 2011 and 2012 with November-December 2013 and 2014 (6 days instead of 45 days).

\subsubsection{A destruction of MSA over the Antarctic plateau under mid-summer conditions}

The preceding observations of a drop of $\mathrm{R}_{\mathrm{MSA}}$ driven by a decrease of MSA level in submicron particles around the beginning of November and its recovery in February, simultaneous with the high photochemical activity at mid-summer at Concordia, suggest the occurrence of a (photo)chemical destruction of MSA taking place in submicron particles at that time. Under conditions encountered in the marine atmosphere, in contrast to its fast heterogeneous production, a significant (but slow) in cloud destruction of MSA is suspected to take place (Von Glasow and Crutzen, 2004; Barnes et al., 2006; Hoffmann et al., 2016). After its production, MSA present in air masses traveling over inland Antarctica will encounter more oxidative conditions, especially when air masses remained for a few days over the high plateau, and is thus characterized by high ozone mixing ratio (see discussions in Legrand et al., 2016). Assuming both the fact that aerosol particles spend about $3 \mathrm{~h}$ per day as cloud droplets and an 

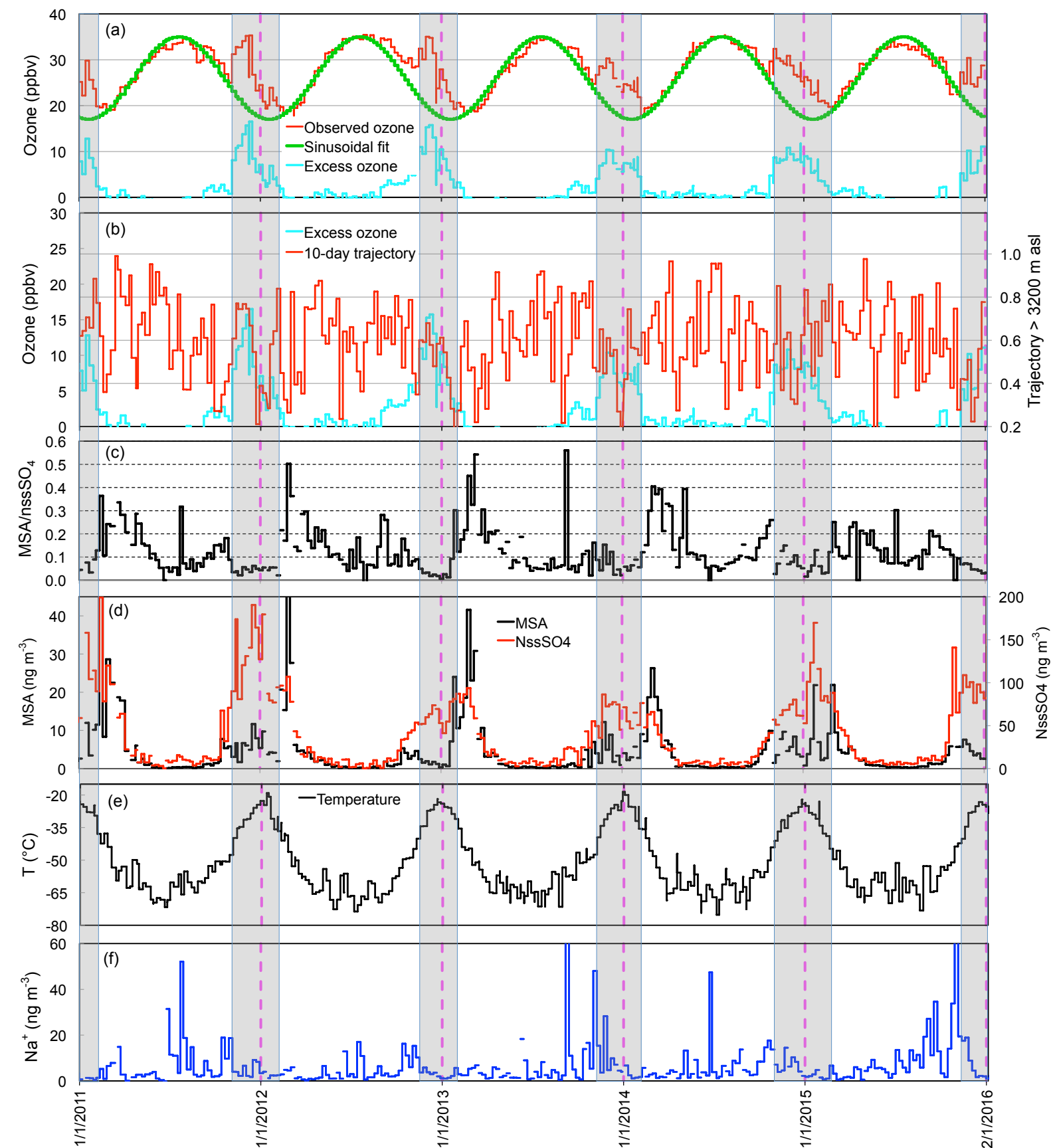

Figure 8. (a) Ozone mixing ratio corresponding to HV aerosol sampling time (red line), a sinusoidal fit of the ozone seasonal cycle (green line), and the amount of ozone present in excess (turquoise line) in summer are reported (see Sect. 3.2.3). (b) Excess ozone (turquoise line) together with the 10-day backward trajectory (arrival at $0 \mathrm{~m}$ a.s.l.) at Concordia (see details in Legrand et al., 2017). The red curve in panel (b) is the fraction of time spent above $3200 \mathrm{~m}$ a.s.l. by the air masses arriving at Concordia. Panels (c) and (d) show $\mathrm{MSA}_{\text {/ nssSO }}$ mass ratio and MSA along with nssSO 4 observed on HV samples, respectively. (e) Air temperature at Concordia. (f) Sodium on HV samples. The grey area denotes the fast decreases of $\mathrm{R}_{\mathrm{MSA}}$ that coincide fairly well with the local $\mathrm{O}_{3}$ photochemical production.

aqueous-phase $\mathrm{OH}\left(\mathrm{OH}_{\mathrm{aq}}\right)$ concentration of $6 \times 10^{-13} \mathrm{M}$, Zhu et al. (2005) calculated a mean lifetime of MSA of 14 days in the marine boundary layer. Clearly, conditions encountered over the Antarctic plateau are very different and it is out of the scope of this paper to identify the involved chemical mechanisms leading to a destruction of MSA in submicron sulfuric acid particles over central Antarctica. We can note, however, that over the Antarctic plateau, while the 
chance of aerosol experiencing aqueous-phase chemistry in cloud droplets is far lower than in the marine boundary layer, the production of $\mathrm{OH}_{\mathrm{aq}}$ from the reaction of ozone with $\mathrm{O}_{2}^{-}$ would be favored compared to conditions encountered in the marine boundary layer due to far more acidic conditions (Ervens et al., 2003). Note also that the dissolution of $\mathrm{H}_{2} \mathrm{O}_{2}$ that also contributes to the budget of $\mathrm{OH}_{\mathrm{aq}}$ would be 2 orders of magnitude higher at Antarctic temperatures than at temperatures encountered in the marine boundary layer.

\subsection{Biogenic vs. non-marine-biogenic source of sulfate inland Antarctica}

\subsubsection{Estimation of non-biogenic sulfate levels from radionuclide data}

Apart from marine biogenic emissions, sulfate present over Antarctica can also originate from southern hemispheric continents or the stratospheric reservoir. ${ }^{210} \mathrm{~Pb}$ data permit one to derive an estimate of the contribution of sulfate longrange transported from continents by comparing the ${ }^{210} \mathrm{~Pb}$ concentrations at Concordia $\left(27 \mu \mathrm{Bq} \mathrm{m}^{-3}\right)$ after having corrected them from marine ${ }^{222} \mathrm{Rn}$ exhalation $(\sim 15 \%$; Weller et al., 2014) (i.e., $23 \mu \mathrm{Bq} \mathrm{m}^{-3}$ ) with those observed at Chacaltaya $\left(407 \mu \mathrm{Bq} \mathrm{m}^{-3}\right.$; Feely et al., 1988), a remote site located at $5220 \mathrm{~m}$ a.s.l. in Bolivia. At this site, a typical sulfate level of $250 \mathrm{ng} \mathrm{m}^{-3}$ can be assumed (see Minikin et al., 1998, and references therein). Note that this value is similar to the one reported by Huebert and Lazrus (1980) for the free troposphere (240 $\mathrm{ng} \mathrm{m}^{-3}$, at 5-6 km elevation over the Pacific ocean). Assuming a sulfate concentration of $250 \mathrm{ng} \mathrm{m}^{-3}$ for the continental free troposphere of the southern hemisphere, and applying a dilution factor of 18 based on ${ }^{210} \mathrm{~Pb}$ data $\left(407 \mu \mathrm{Bq} \mathrm{m}{ }^{-3}\right.$ at Chacaltaya compared to $23 \mu \mathrm{Bq} \mathrm{m}^{-3}$ at Concordia), we calculate a mean sulfate concentration of $14 \mathrm{ng} \mathrm{m}^{-3}$. The ${ }^{210} \mathrm{~Pb}$ activities at Concordia (Fig. 2) show an enhancement by a factor of 2.5 from June-September to November-February, leading to an estimated concentration of continental sulfate of 8 and $20 \mathrm{ng} \mathrm{m}^{-3}$, respectively. These values may be overestimated since an influence of the city of La Paz ( $3600 \mathrm{~m}$ a.s.l., located only at $25 \mathrm{~km}$ away from the Chacaltaya site) on the sulfate concentration remains here possible. Note also that other continents, such as Australia, certainly contribute to the long-range transport of continental ${ }^{210} \mathrm{~Pb}$ and sulfate towards Antarctica, in particular in the case of East Antarctica (Heimann et al., 1990).

For the first time, ${ }^{10} \mathrm{Be}$ concentrations are documented in the atmosphere of the high East Antarctic plateau (Fig. 9). The seasonal cycle characterized by a winter minimum and a January-February maximum is similar to what was observed at the coastal site of Neumayer by Elsässer et al. (2011) but with a far stronger winter-summer amplitude (a factor of 10 at Concordia instead of 2-3 at NM). This difference is likely reflecting (1) the particularly strong inversion layer in winter at inland Antarctica and (2) higher summer concentrations at

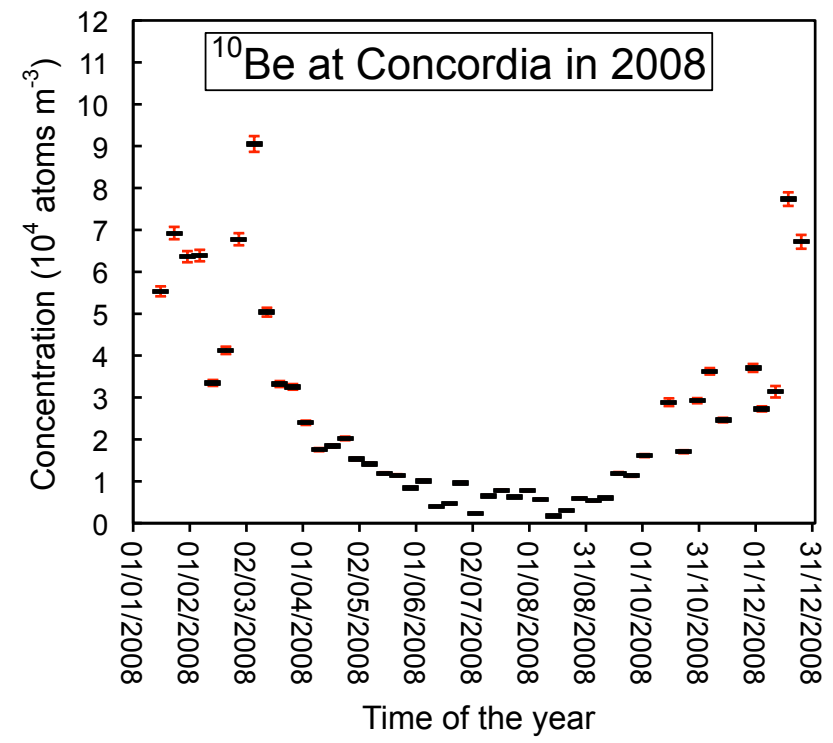

Figure 9. Annual cycle of ${ }^{10} \mathrm{Be}$ concentrations in 2008 at Concordia. Vertical bars (in red) refer to AMS uncertainties (see Sect. 2).

$3200 \mathrm{~m}$ a.s.l. than at the sea level. From the observation of a mean winter concentration of ${ }^{10} \mathrm{Be}$ of $0.6 \times 10^{4}$ atoms $\mathrm{m}^{-3}$ at Concordia (Fig. 9) and considering the ${ }^{10} \mathrm{Be}$ concentration of $10^{7}$ and $0.5 \times 10^{7}$ atoms $\mathrm{m}^{-3}$ observed between 11 and $19 \mathrm{~km}$ elevation at $65^{\circ} \mathrm{N}$ by Raisbeck et al. (1981) and Field et al. (2006), respectively, we derive a dilution factor in the range of 800-1700 between the lower stratosphere and the atmosphere at Concordia in winter. Lazrus et al. (1979) measured worldwide background (non-volcanic) sulfate mixing ratios from $0.1 \mathrm{ppbm}$ at $11 \mathrm{~km}$ elevation to $0.5 \mathrm{ppbm}$ at $19 \mathrm{~km}$ elevation. Considering a mean sulfate mixing ratio of $0.3 \mathrm{ppbm}$ for the lower stratosphere, and the typical dilution factor observed for ${ }^{10} \mathrm{Be}$ between the lower stratosphere and the atmosphere at Concordia, we estimate that stratospherictropospheric exchange may account for $0.4 \mathrm{ng} \mathrm{m}^{-3}$ of sulfate in winter at Concordia. As shown in Table 3, similarly to what was previously shown for NM (Wagenbach, 1996), an increase of ${ }^{7} \mathrm{Be} /{ }^{210} \mathrm{~Pb}$ and ${ }^{10} \mathrm{Be} /{ }^{7} \mathrm{Be}$ ratios from winter to summer is seen at Concordia, suggesting a 2 times stronger downward transport from the stratosphere in summer than in winter there.

Beryllium data do not account for sulfate transported downward from the lower stratosphere during sedimentation of polar stratospheric clouds that occurs without stratospheric-tropospheric air mass exchange. Measurements of ${ }^{35} \mathrm{~S}$ that offer the possibility to estimate stratospheric input of sulfur were done on aerosol collected at Concordia, showing that as upper estimates $3.3 \mathrm{ng} \mathrm{m}^{-3}$ of sulfate in winter and $16.5 \mathrm{ng} \mathrm{m}^{-3}$ in summer/fall come from the lower stratosphere (Hill-Falkenthal et al., 2013). 
Table 3. Monthly data of atmospheric ${ }^{10} \mathrm{Be}$ and ${ }^{7} \mathrm{Be}$ at Concordia along with tracers of arrival of stratospheric aerosols $\left({ }^{10} \mathrm{Be} /{ }^{7} \mathrm{Be}\right.$ as atom ratio and ${ }^{7} \mathrm{Be} /{ }^{210} \mathrm{~Pb}$ as activity ratio).

\begin{tabular}{lrrrr}
\hline Months & $\begin{array}{r}{ }^{10} \mathrm{Be} \\
\left(\text { atoms }^{-3}\right)\end{array}$ & $\begin{array}{r}{ }^{7} \mathrm{Be} \\
\left(\text { atoms }^{-3}\right)\end{array}$ & $\begin{array}{r}10 \mathrm{Be} /{ }^{7} \mathrm{Be} \\
\text { (atom) }\end{array}$ & $\begin{array}{r}{ }^{7} \mathrm{Be} /{ }^{210} \mathrm{~Pb} \\
\text { (activity) }\end{array}$ \\
\hline Jan & 6.2 & 3.6 & 2.0 & 122 \\
Feb & 5.2 & NA & NA & NA \\
Mar & 6.0 & NA & NA & NA \\
Apr & 2.3 & NA & NA & NA \\
May & 1.3 & 1.5 & 0.9 & 96 \\
Jun & 0.7 & NA & NA & NA \\
Jul & 0.6 & NA & NA & NA \\
Aug & 0.5 & 0.8 & 0.6 & 82 \\
Sep & 0.8 & 1.4 & 0.6 & 78 \\
Oct & 2.1 & 2.4 & 1.1 & 88 \\
Nov & 3.0 & 2.8 & 1.2 & 85 \\
Dec & 4.8 & 3.8 & 1.5 & 140 \\
\hline
\end{tabular}

NA: not available

\subsubsection{Estimation of non-biogenic sulfate levels from the nsSSO$_{4}-\mathrm{MSA}_{\text {relationship }}$}

The preceding discussions have shown how uncertain estimates of the contribution of non-biogenic source of sulfate over the Antarctic plateau remain based on radionuclide data, except for the downward transport from the stratosphere as traced back using beryllium $\left({ }^{10} \mathrm{Be}\right.$ and $\left.{ }^{7} \mathrm{Be}\right)$.

The initial motivation to conduct simultaneous measurements of MSA and sulfate in Antarctic air or snow was to separate the marine biogenic source of non-sea-salt sulfate from others like volcanic emissions, anthropogenic sources, and terrestrial sources. It was expected that the examination of the relationship between $\mathrm{nssSO}_{4}$ and MSA would help. However, several previous studies pointed out that the quantification of the non-biogenic sulfate sources by examination of the $y$ intercept of the relationship between $\mathrm{nssSO}_{4}$ and MSA is complicated by the fact that $\mathrm{R}_{\mathrm{MSA}}$ is seasonally dependent and varies with the MSA concentration range; see for instance Legrand and Pasteur (1998) and Piel et al. (2006). Figure 10 illustrates how poor the correlation between the two sulfur species is at Concordia $\left(\left[\mathrm{nssSO}_{4}\right]=6.0[\mathrm{MSA}]+14\right.$ with $R^{2}=0.33$; Table 4$)$. As recommended by Ayers (2001), we here used a bivariate regression (so called reduced major axis regression). As clearly shown by Fig. 10a, the scattering of the correlation is largely due to summer samples $\left(R^{2}=0.37\right.$ for summer samples as shown with red points). Since, as previously discussed, a destruction of MSA takes place in summer at Concordia, leading to unusually low $\mathrm{R}_{\text {MSA }}$ values (even lower than in winter), we have scrutinized the correlation only considering data corresponding to the rest of the year (i.e., considering only black points shown in Fig. 10a). For these samples, which cover the spring to fall time period, a far better correlation is observed $\left(\left[\mathrm{nsSSO}_{4}\right]=3.5[\mathrm{MSA}]+7\right.$ with $R^{2}=0.80$, Table 4). However, the significant change of $R_{M S A}$ from

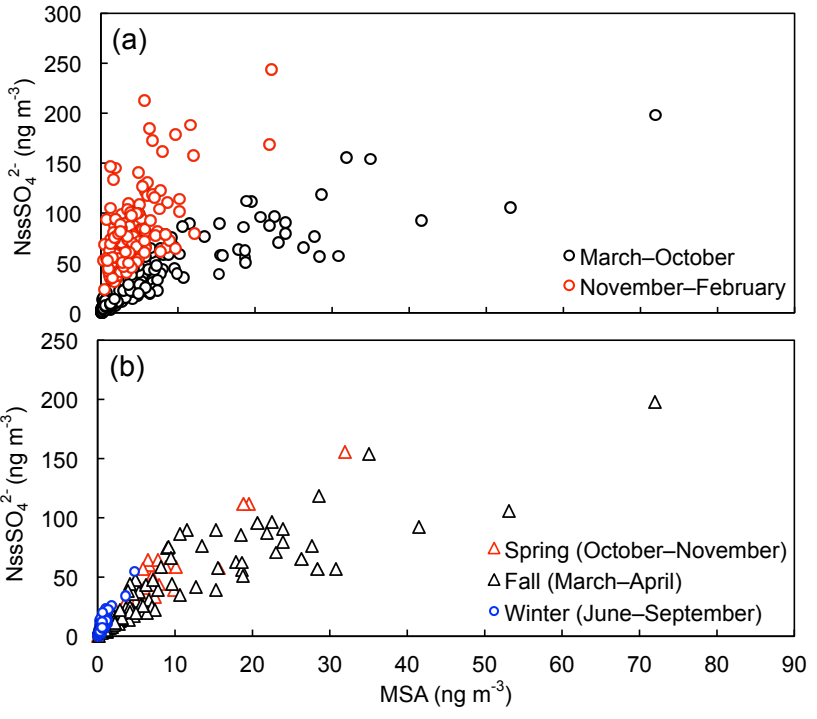

Figure 10. Correlation of $\mathrm{nssSO}_{4}$ with MSA concentrations observed at Concordia on HV bulk aerosol samples. (a) All data (red circles highlight mid-summer samples); (b) spring to fall samples.

Table 4. Slope and $y$ intercept ( \pm standard error estimate) of the linear regression between nssSO ${ }_{4}^{2-}$ and MSA levels as a function of season at Concordia.

\begin{tabular}{lrrr}
\hline Data set & Slope & $y$ intercept & $R^{2}$ \\
\hline All data & $6.0 \pm 0.3$ & $14 \pm 3$ & 0.33 \\
All data excluding summer & $3.5 \pm 0.1$ & $7 \pm 1$ & 0.80 \\
Summer & $11.2 \pm 0.9$ & $35 \pm 8$ & 0.37 \\
Winter & $15.2 \pm 1.0$ & $0.0 \pm 1$ & 0.65 \\
Spring & $5.1 \pm 0.3$ & $9 \pm 4$ & 0.89 \\
Fall & $2.9 \pm 0.2$ & $12 \pm 5$ & 0.75 \\
\hline
\end{tabular}

spring to fall still leads to an overestimation of non-biogenic sulfate when considering the $y$ intercept of the linear regression line. In the following, we therefore scrutinize separately spring, fall, and winter data (red triangles, black triangles, and blue circles in Fig. 11, respectively).

In winter, both nssSO ${ }_{4}$ and MSA exhibit low concentrations (Fig. 2). Nevertheless, as suggested by increases of ${ }^{210} \mathrm{~Pb}$, the isolation of the high Antarctic plateau from the free Antarctic troposphere sometimes breaks down, often resulting from arrival of warm air associated with a marine intrusion. As seen in Fig. 12, under these conditions, the increase of ${ }^{210} \mathrm{~Pb}$ is accompanied by an increase of sulfate, suggesting that the lower troposphere at Concordia was temporary filled with winter free-tropospheric air. Interestingly, Fig. 2 shows that the highest mean winter levels of $\mathrm{nsSSO}_{4}$ occurred in $2011\left(8.0 \pm 3.9 \mathrm{ng} \mathrm{m}^{-3}\right)$ and 2013 $\left(8.1 \pm 5.6 \mathrm{ng} \mathrm{m}^{-3}\right)$, when the ${ }^{210} \mathrm{~Pb}$ levels were also the highest of the record $\left(22-24 \mu \mathrm{Bq} \mathrm{m}^{-3}\right)$. Conversely, the lowest $\mathrm{nssSO}_{4}$ mean winter level is observed in 2008 when the level 

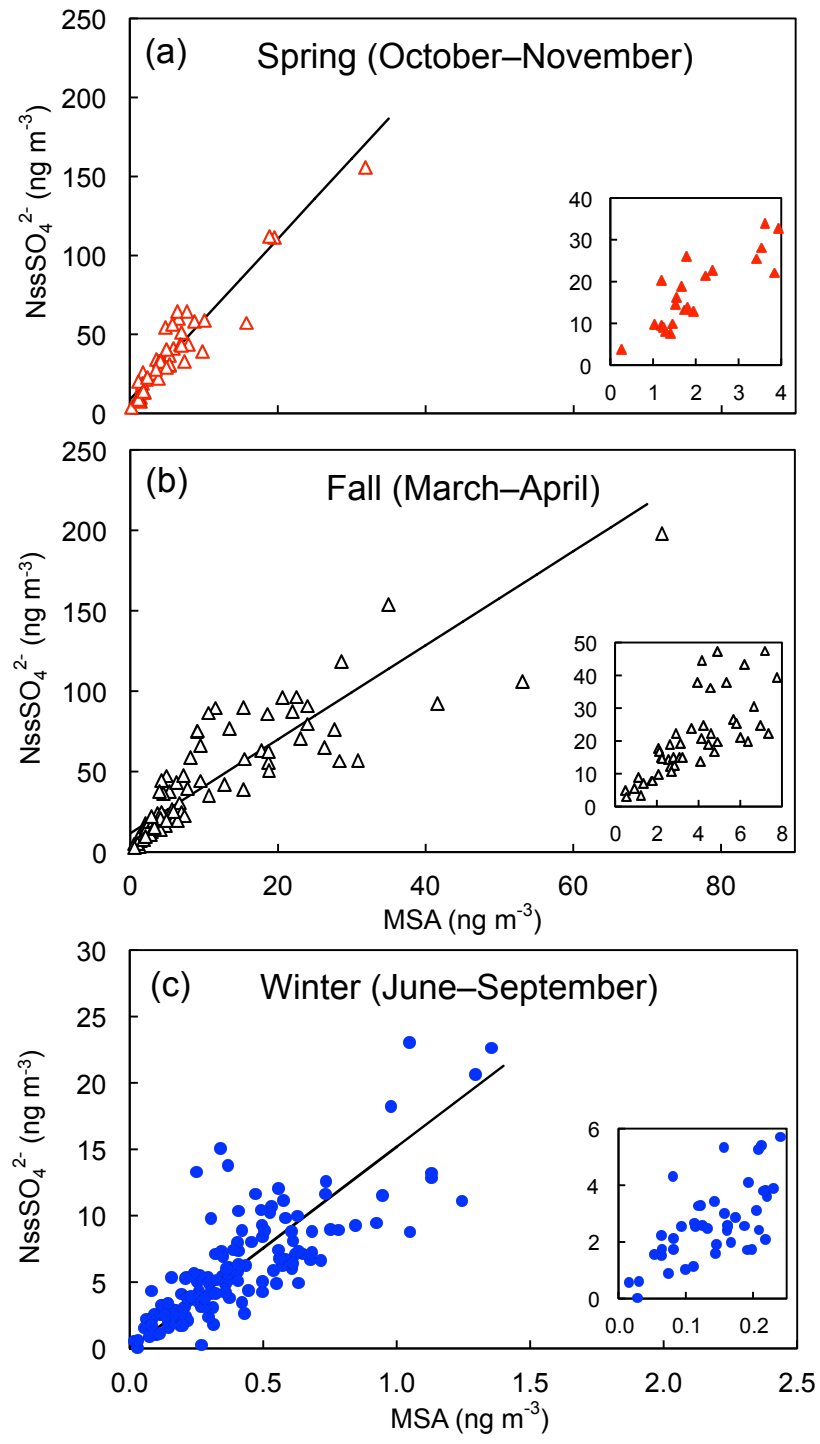

Figure 11. Correlation of $\mathrm{nsSSO}_{4}$ with MSA concentrations observed at Concordia on HV bulk aerosol samples collected in spring (a), fall (b), and winter (c). The paneled-in figures highlight the correlation at MSA concentrations close to zero.

of ${ }^{210} \mathrm{~Pb}$ was particularly low $\left(11 \mu \mathrm{Bq} \mathrm{m}{ }^{-3}\right)$. In the following we examine the origin of sulfate present in the freetropospheric winter atmosphere. As shown in Fig. 11c, the slope of the linear relationship between $\mathrm{nssSO}_{4}$ and MSA $\left(\left[\mathrm{nssSO}_{4}\right]=15.2[\mathrm{MSA}]+0\right.$ with $R^{2}=0.65$, Table 4) corresponds to a $R_{M S A}$ value of $0.066 \pm 0.004$. Such a $R_{M S A}$ value below 0.10 in winter is typically observed in the remote marine boundary layer at low- to mid-southern latitudes in winter (from April to September): 0.077 at $40^{\circ} \mathrm{S}$ (Cap Grim; Ayers et al., 1991), 0.037 at $29^{\circ} \mathrm{S}$ (Norfolk; Saltzman et al., 1986), and 0.026 at $22^{\circ} \mathrm{S}$ (New Caledonia; Saltzman et al., 1986). The $y$ intercept of the linear relationship $\left(0 \pm 1 \mathrm{ng} \mathrm{m}^{-3}\right.$; Table 4$)$ suggests that in winter, when marine

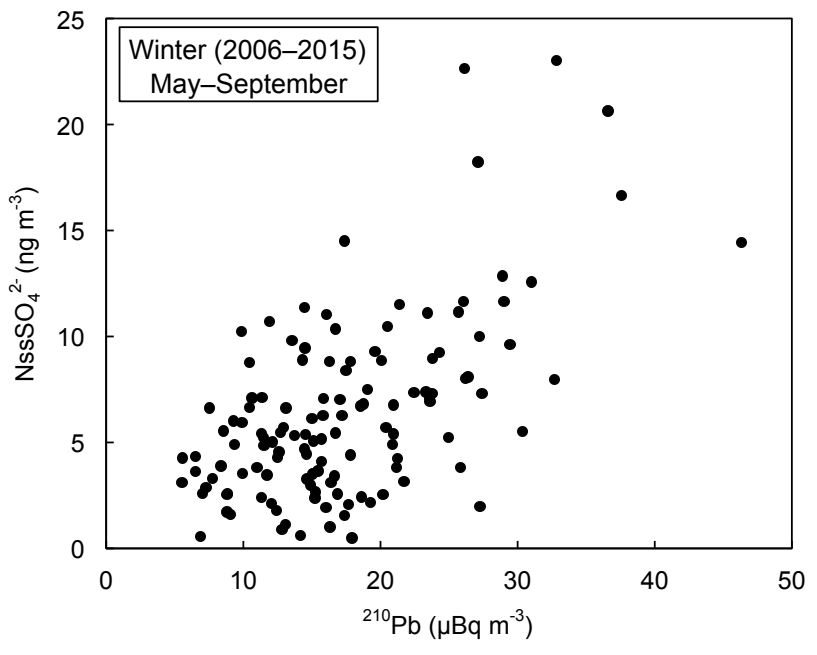

Figure 12. $\mathrm{NssSO}_{4}$ vs. ${ }^{210} \mathrm{~Pb}$ concentrations on $\mathrm{HV}$ filters collected in winter (May-September) at Concordia between 2006 and 2015.

biogenic emissions are located far away from the Antarctic continent, the contribution of non-biogenic source to $\mathrm{nsSSO}_{4}$ remains at the best limited to around $1 \mathrm{ng} \mathrm{m}^{-3}$ (for a total $\mathrm{nssSO}_{4}$ concentration of $6 \pm 4 \mathrm{ng} \mathrm{m}^{-3}$ ).

In spring, the linear relationship between $\mathrm{nssSO}_{4}$ and MSA $\left(\left[\mathrm{nsSO}_{4}\right]=5.1[\mathrm{MSA}]+9\right.$ with $R^{2}=0.89$; Table 4) suggests an increase of $\mathrm{R}_{\mathrm{MSA}}$ compared to winter (0.20 instead of 0.07 in winter). This increase of $\mathrm{R}_{\mathrm{MSA}}$ from winter to spring likely reflects the enhanced contribution of DMS emissions from marine area located south of $50^{\circ} \mathrm{S}$ as shown by the increase of oceanic chlorophyll (Fig. 2). In contrast to winter, the linear relationship between $\mathrm{nsSO}_{4}$ and MSA observed in spring suggests the existence of a non-biogenic sulfate source accounting for a few $\mathrm{ng} \mathrm{m}^{-3}$. The non-linearity of the relation between $\mathrm{nsSSO}_{4}$ and MSA tends, however, to overestimate the $y$ intercept (Fig. 11a); a $y$ intercept of around $3 \mathrm{ng} \mathrm{m}^{-3}$ is obtained when samples with less than $5 \mathrm{ng} \mathrm{m}^{-3}$ of MSA are considered.

In fall, the relationship between $\mathrm{nssSO}_{4}$ and MSA becomes even less linear than in spring, rendering rather inaccurate the use of the $y$ intercept in evaluating the nonbiogenic sulfate contribution (Fig. 11b). However, Fig. 11b suggests that, if significant, the non-biogenic sulfate concentration remains well below $5 \mathrm{ng} \mathrm{m}^{-3}$ at that time. The slope of the relationship between $\mathrm{nssSO}_{4}$ and MSA in fall $(2.9 \pm 0.2$, Table 4$)$ indicates a further increase of $\mathrm{R}_{\mathrm{MSA}}$ compared to spring (0.34 instead of 0.20 in spring). Comparing November and March, Fig. 2 indicates that a decrease of oceanic chlorophyll concentrations have started between 50 and $60^{\circ} \mathrm{S}$ whereas those at latitudes higher than $60^{\circ} \mathrm{S}$ are maintained or slightly higher in March than in November. That can explain the higher $\mathrm{R}_{\mathrm{MSA}}$ values in March compared to November. Note that such a higher $\mathrm{R}_{\mathrm{MSA}}$ in March compared to November is also observed at coastal sites (Fig. 3). 
Table 5. MSA / nssSO $_{4}$ ratios $\left(\mathrm{R}_{\mathrm{MSA}}\right)$ observed at coastal Antarctic sites in January and March: Neumayer and Halley facing the Atlantic ocean and Dumont d'Urville and Mawson the Indian ocean.

\begin{tabular}{lrll}
\hline Site & R $_{\text {MSA }}$ & Month/year & References \\
\hline Neumayer & $0.41 \pm 0.13$ & Jan 1984-1995 & Legrand and Pasteur (1998) \\
$\left(70^{\circ} \mathrm{S}, 8^{\circ} \mathrm{W}\right)$ & $0.27 \pm 0.10$ & Mar 1983-1994 & \\
Halley & $0.43 \pm 0.03$ & Jan 1992-1993 & Legrand and Pasteur (1998) \\
$\left(75^{\circ} \mathrm{S}, 26^{\circ} \mathrm{W}\right)$ & $0.35 \pm 0.12$ & Mar 1991-1992 & \\
Mawson & $0.23 \pm 0.05$ & Jan 1988-1991 & Legrand and Pasteur (1998), \\
$\left(67^{\circ} \mathrm{S}, 62^{\circ} \mathrm{E}\right)$ & $0.31 \pm 0.07$ & Mar 1988-1991 & Savoie et al. (1992) \\
Dumont d'Urville & $0.21 \pm 0.05^{*}$ & Jan 1991-1996 & Jourdain and Legrand (2002) \\
$\left(66^{\circ} \mathrm{S}, 140^{\circ} \mathrm{E}\right)$ & $0.33 \pm 0.06^{*}$ & Mar 1991-1996 & \\
\hline
\end{tabular}

* The values are slightly higher than those reported by Legrand and Pasteur (1998) $(0.16 \pm 0.01$ in January and $0.25 \pm 0.04$ in March) since, following Jourdain and Legrand (2002), they were calculated after having subtracted the contribution of ornithogenic soils to the sodium and sulfate levels.

To minimize the uncertainties related to the variability of $\mathrm{R}_{\text {MSA }}$ between the different samples, we also examined the relationship between non-sea-salt sulfate and MSA concentrations on the 12 stages of impactor run. This approach reduces the uncertainty linked to variability of $\mathrm{R}_{\text {MSA }}$ value over time. A few impactor runs show a $y$ intercept that was significantly different from zero, reaching $1 \mathrm{ng} \mathrm{m}^{-3}$ in winter and 1 to $4 \mathrm{ng} \mathrm{m}^{-3}$ at other seasons.

It can therefore be concluded that, whatever the season, marine biogenic emissions of DMS dominate the atmospheric budget of sulfate over inland Antarctica. If it exists, the contribution of non-biogenic sulfate source remains limited to $1 \mathrm{ng} \mathrm{m}^{-3}$ in winter and possibly reaches a few $\mathrm{ng} \mathrm{m}^{-3}$ particular from spring to fall. Previous discussions on radionuclide data gained at Concordia suggest the long-range transported sulfate from continent in spring and/or summer and downward transport from the lower stratosphere particularly in summer and/or fall as non-biogenic sources of sulfate.

\section{Coastal Antarctica in summer}

As seen in Table 5, in summer there is a systematic difference in the sulfur aerosol composition at sites facing the Atlantic sector compared to those facing the Indian sector. Whereas a mean $\mathrm{R}_{\text {MSA }}$ value close to 0.3 is observed at all sites in March, a summer $\mathrm{R}_{\text {MSA }}$ maximum of 0.4 occurs in January at NM and Halley (Ha) (Atlantic sector) when the $\mathrm{R}_{\text {MSA value }}$ remains close to 0.2 at DDU and Mawson (Indian sector). The corresponding relatively weak abundance of MSA compared to $\mathrm{nssSO}_{4}$ in January at DDU and Mawson compared to NM and Ha may be related to a destruction of MSA that acts more efficiently in the Atlantic than Indian margin regions. Indeed the level of various oxidants was found to be unusually high at DDU compared to the situation at Ha. For instance, Kukui et al. (2012) reported a mean $\mathrm{OH}$ concentration of $2.1 \times 10^{6}$ radical cm $^{-3}$ at DDU versus $0.39 \times 10^{6} \mathrm{rad}-$ ical $\mathrm{cm}^{-3}$ at $\mathrm{Ha}$ (Bloss et al., 2010). Note that $\mathrm{OH}$ concentra- tions at DDU are still in the range of those observed at Concordia $\left(3.1 \times 10^{6}\right.$ radical $\mathrm{cm}^{-3}$; Kukui et al., 2014). Concerning ozone, Legrand et al. (2016) compared records from NM and Ha with those of DDU and Syowa, a site also facing the Indian sector. They found that in December, more frequently high ozone values (17\% above $25 \mathrm{ppbv}, 33 \%$ above $22 \mathrm{ppbv}$ ) are observed at DDU compared to NM (1\% above $25 \mathrm{ppbv}$, $5 \%$ above $22 \mathrm{ppbv}$ ) and $\mathrm{Ha}(<1 \%$ above $25 \mathrm{ppbv}, 1 \%$ above $22 \mathrm{ppbv})$. For the case of Syowa, an intermediate situation is observed with $2.5 \%$ of values above $25 \mathrm{ppbv}$, and $12 \%$ of values above 22 ppbv. These differences were attributed to the fact that ozone-rich air masses present in summer over the inland Antarctic plateau are more efficiently transported to DDU and Mawson than to NM and Ha. Since the nearsurface airflow between the Antarctic plateau and the coastal regions is largely controlled by the topography of the underlying ice sheets and the vicinity of low-pressure systems on the coast of the Antarctic continent, the transport of air mass from inland Antarctica to margin regions is far more important at DDU and Mawson than at NM and Ha (Parish and Bromwich, 2007). These differences in the oxidative property of the atmosphere may lead to larger destruction of MSA and therefore to a decrease of the $\mathrm{R}_{\mathrm{MSA}}$ ratio at DDU and Mawson compared to NM and Ha, as seen in Table 4.

\section{Implications for the $\mathbf{R}_{\text {MSA }}$ ratio in Antarctic ice}

In the present-day (2006-2015) aerosol at Concordia, we observe an annual mean level of MSA and $\mathrm{nssSO}_{4}$ of 4 and $38 \mathrm{ng} \mathrm{m}^{-3}$, respectively, with a grand average $R_{M S A}$ value of 0.11. Assuming a similar air-snow relationship for MSA and $\mathrm{nssSO}_{4}$ aerosol and referring to the mean level of sulfate observed in the Holocene ice (0-10 kry BP) at DC (100 ppb; Wolff et al., 2006), we would expect a corresponding level of MSA in ice of $12 \mathrm{ppb}$. The lower MSA value observed in the ice deposited during the Holocene at DC (from 1 to 5 ppb; Saigne and Legrand, 1987) indicates that, in addition to the previously discussed destruction of MSA in the atmo- 
sphere of central Antarctica, post-depositional effects also contribute to the low $\mathrm{R}_{\mathrm{MSA}}$ value seen in ice at that site.

Though year-round MSA data are not available at the South Pole, the drop of $\mathrm{R}_{\mathrm{MSA}}$ values seen at Concordia during mid-summer is also observed at the South Pole (see Table 2), supporting the relevance of an annual $\mathrm{R}_{\mathrm{MSA}}$ of 0.11 for the atmosphere at the scale of the whole Antarctic plateau. If confirmed, a $\mathrm{R}_{\mathrm{MSA}}$ value of 0.11 in the atmosphere at the South Pole is consistent with $\mathrm{R}_{\mathrm{MSA}}$ observed in south polar snow layers, 0.13 over the last century (Legrand and Feniet-Saigne, 1991), and from 0.08 to 0.15 over the last millennium (Feniet-Saigne, 1984). That also suggested that, if they occur, post-depositional effects remains rather limited at that site.

At Vostok, whereas $\mathrm{R}_{\mathrm{MSA}}$ values ranging around 0.15 were observed in the upper $2 \mathrm{~m}$ of snow (Wagnon et al., 1999), an averaged value of 0.05 is found in ice deposited over the last 10 kyr BP (Legrand et al., 1991). Therefore, in contrast to the case of the South Pole where atmospheric process can alone explained the relatively low $\mathrm{R}_{\mathrm{MSA}}$ values, at sites characterized by lower snow accumulation rates like Vostok and Concordia ( 2 and $3 \mathrm{~g} \mathrm{~cm}^{-2} \mathrm{yr}^{-1}$, respectively, instead of $8 \mathrm{~g} \mathrm{~cm}^{-2} \mathrm{yr}^{-1}$ at the South Pole), there are also post-depositional destruction or release of MSA within the snowpack. Further measurements including gas-phase MSA would be needed at Concordia to conclude on the causes of post-deposition decrease of MSA in snow (re-emission into the gas-phase or in situ chemical destruction).

\section{Conclusions}

Load and composition of sulfur-derived aerosol (methanesulfonate and non-sea-salt sulfate) at inland East Antarctica are documented from multiple year-round records of bulk aerosol samplings and, for the first time in central Antarctica, the size-segregated composition of aerosol ( $0.03-20 \mu \mathrm{m}$ diameter). A striking difference in the seasonality of sulfur aerosol composition, characterized by a MSA to $\mathrm{nssSO}_{4}$ ratio reaching a minimum in December-January over the Antarctic plateau (0.05) and a maximum at the coast (up to 0.40 at sites facing the Atlantic oceanic sector), is clearly established. We find that the low value of $\mathrm{R}_{\mathrm{MSA}}$ in mid-summer at Concordia is due to a drop of MSA concentrations that occurs in the small particles $(0.3 \mu \mathrm{m}$ diameter $)$ of sulfuric acid aerosol. The drop of MSA coincides with periods of high photochemical activity as indicated by the presence of ozone locally photochemically produced, strongly suggesting the occurrence of an efficient chemical destruction of MSA over the Antarctic plateau in mid-summer. The examination of the relationship between MSA and $\mathrm{nsSOO}_{4}$ levels indicates a non-biogenic sulfate level that does not exceed $1 \mathrm{ng} \mathrm{m}^{-3}$ in fall and winter and remains below $5 \mathrm{ng} \mathrm{m}^{-3}$ in spring. Thanks to atmospheric ${ }^{10} \mathrm{Be},{ }^{7} \mathrm{Be}$, and ${ }^{210} \mathrm{~Pb}$ data gained at Concordia, this weak level of non-biogenic sulfate over the Antarctic plateau is discussed with respect to the contribution of the stratosphere and of the long-range transport of sulfate from continents. The observed increases of $\mathrm{R}_{\mathrm{MSA}}$ values from winter to spring and spring to fall reflect change over the course of the year of marine source regions contributing to the sulfur load inland Antarctica, with marine emissions mainly located at temperate latitudes in winter and a progressive recovery of high-latitude DMS emissions in spring-summer-fall. The findings demonstrate that the relatively low $\mathrm{R}_{\mathrm{MSA}}$ observed in the ice deposited over the plateau compared to that at coastal Antarctica reflects at the first degree the atmospheric behavior of sulfur-derived aerosol, although, at least at sites with low snow accumulation rate, a loss of MSA from the snowpack due to either chemical destruction or re-emission occurs there.

Data availability. Data on the chemical composition of aerosol (bulk and size-segregated composition) at Concordia can be made available for scientific purposes upon request to the authors (contact michel.legrand@univ-grenoble-alpes.fr or suzanne.preunkert@univ-grenoble-alpes.fr). Original ${ }^{10} \mathrm{Be}$ and

${ }^{9}$ Be can be obtained by contacting HZDR (s.merchel@hzdr.de).

Author contributions. Dietmar Wagenbach contributed to the setup and monitoring of the HV filter sampling at Concordia. He also initiated, with Michel Legrand, the discussions on the scientific topics which are discussed in this paper and its companion, but he passed away before submission.

Competing interests. The authors declare that they have no conflict of interest.

Acknowledgements. National financial support and field logistic supplies for the summer campaign were provided by the Institut Polaire Français Paul Emile Victor (IPEV) through program nos. 414 and 903 and the Agence Nationale de la Recherche through contract ANR-14-CE01-0001-01 (ASUMA). This work was initiated in the framework of the French environmental observation service CESOA (Étude du cycle atmosphérique du soufre en relation avec le climat aux moyennes et hautes latitudes sud) with the financial support of INSU (CNRS). We thank Bruno Jourdain from LGGE for supervising the sampling material in the field and for sample analysis. Thanks also to Eric Wolff from Cambridge for useful discussions. Parts of this research were carried out at the Ion Beam Centre (IBC) at the Helmholtz-Zentrum Dresden-Rossendorf e.V., a member of the Helmholtz Association. We would like to thank the DREAMS operator team, René Ziegenrücker and Stefan Pavetich for their assistance with AMS measurements, and Stephanie Uhlig for help with ${ }^{10} \mathrm{Be}$ sample preparation. We thank the two anonymous reviewers for their helpful comments.

Edited by: Veli-Matti Kerminen

Reviewed by: two anonymous referees 


\section{References}

Arimoto, R., Nottingham, A. S., Webb, J., Schloesslin, C. A., and Davis, D.: Non-sea-salt sulfate and other aerosol constituents at the South Pole during ISCAT, Geophys. Res. Lett., 28, 3645$3648,2001$.

Arimoto, R., Hogan, A., Grube, P., Davis, D., Webb, J., Schloesslin, C., Sage, S., and Raccah, F.: Major ions and radionuclides in aerosol particles from the South Pole during ISCAT-2000, Atmos. Environ., 38, 5473-5484, 2004.

Arimoto, R., Zeng, T., Davis, D., Wang, Y., Khaing, H., Nesbit, C., and Huey, G.: Concentrations and sources of aerosol ions and trace elements during ANTCI-2003, Atmos. Environ., 42, 2864 2876, https://doi.org/10.1016/j.atmosenv.2007.05.054, 2008.

Ayers, G. P.: Comment on regression analysis of air quality data, Atmos. Environ., 35, 2423-2425, 2001.

Ayers, G. P., Ivey, J. P., and Gillett, R. W.: Coherence between seasonal cycles of dimethylsulphide, methanesulphonate and sulphate in marine air, Nature, 349, 404-406, 1991.

Bardouki, H., Barcellos da Rosa, M., Mihalopoulos, N., Palm, W.U., and Zetzsch, C.: Kinetics and mechanism of the oxidation of dimethylsulfoxide (DMSO) and methanesulfinate $\left(\mathrm{MSI}^{-}\right)$by $\mathrm{OH}$ radicals in aqueous medium, Atmos. Environ., 36, 46274634, https://doi.org/10.1016/S1352-2310(02)00460-0, 2002.

Barnes, I., Hjorth, J., and Mihalopoulos, N.: Dimethyl sulphide and dimethyl sulfoxide and their oxidation in the atmosphere, Chem. Rev., 106, 940-975, https://doi.org/10.1021/cr020529+, 2006.

Bates, T. S., Calhoun, J. A., and Quinn, P. K.: Variations in the methanesulfonate to sulfate molar ratio in submicrometer marine aerosol particles over the South Pacific Ocean, J. Geophys. Res., 97, 9859-9865, 1992.

Becagli, S, Scarchilli, C., Traversi, R., Dayan, U., Severi, M., Frosini, D., Vitale, V., Mazzola, M., Lupi, A., Nava, S., and Udisti, R.: Study of present-day sources and transport processes affecting oxidised sulphur compounds in atmospheric aerosols at Dome C (Antarctica) from year-round sampling campaigns, Atmos. Environ., 52, 98-108, 2012.

Bloss, W. J., Camredon, M., Lee, J. D., Heard, D. E., Plane, J. M. C., Saiz-Lopez, A., Bauguitte, S. J.-B., Salmon, R. A., and Jones, A. E.: Coupling of HOx, NOx and halogen chemistry in the antarctic boundary layer, Atmos. Chem. Phys., 10, 1018710209, https://doi.org/10.5194/acp-10-10187-2010, 2010.

Charlson, R. J., Lovelock, J. E., Andreae, M. O., and Warren, S. G.: Oceanic phytoplankton, tropospheric sulphur, cloud albedo and climate, Nature, 326, 655-661, 1987.

Crawford, J. H., Davis, D. D., Chen, G., Buhr, M., Oltmans, S., Weller, R., Mauldin, L., Eisele, F., Shetter, R., Lefer, B., Arimoto, R., and Hogan, A.: Evidence for photochemical production of ozone at the South Pole surface, Geophys. Res. Lett., 28, 36413644, 2001.

Curran, M. A. J., van Ommen, T. D., Morgan, V. I., Phillips, K. L., and Palmer, A. S.: Ice core evidence for Antarctic sea ice decline since the 1950s, Science, 302, 1203-1206, 2003.

Davis, D. D., Chen, G., Kasibhatla, P., Jefferson, A., Tanner, D., Eisele, F., Lenschow, D., Neff, W., and Berresheim, H.: DMS oxidation in the Antarctic marine boundary layer: Comparison of model simulations and field observations of DMS, DMSO, $\mathrm{DMSO}_{2}, \mathrm{H}_{2} \mathrm{SO}_{4}(\mathrm{~g}), \mathrm{MSA}(\mathrm{g})$, and MSA(p), J. Geophys. Res., 103, 1657-1678, https://doi.org/10.1029/97JD03452, 1998.
Davis, D. D., Nowak, L. B., Chen, G., Buhr, M., Arimoto, R., Hogan, A., Eisele, F., Mauldin, L., Tanner, D., Shetter, R., Lefer, B., and McMurry, P.: Unexpected high levels of NO observed at South Pole, Geophys. Res. Lett., 28, 3625-3628, 2001.

Delmas, R. J., Wagnon, P., Goto-Azuma, K., Kamiyama, K., and Watanabe, O.: Evidence for the loss of snow-deposited MSA to the interstitial gaseous phase in central Antarctic firn, Tellus B, 55, 71-79, 2003.

Elsässer, C., Wagenbach, D, Weller, R., Auer, M., Wallner, A., and Christl, M.: Continuous 25-years aerosol records at coastal Antarctica: Part II. Variability of the radionuclides ${ }^{7} \mathrm{Be},{ }^{10} \mathrm{Be}$ and ${ }^{210} \mathrm{~Pb}$, Tellus B, 63, 920-934, 2011.

Ervens, B., George, C., Williams, J. E., Buxton, G. V., Salmon, G. A., Bydder, M., Wilkinson, F., Dentener, F., Mirabel, P., Wolke, R., and Herrmann, H.: CAPRAM 2.4 (MODAC mechanism): An extended and condensed tropospheric aqueous phase mechanism and its application, J. Geophys. Res., 108, 4426, https://doi.org/10.1029/2002JD002202, 2003.

Feely, H. W., Larsen, R. J., and Sanderson, C. G.: Annual report of the surface air sampling program, Environmental Measurements Laboratory, Report EML 497, 1988.

Feniet-Saigne, C.: L'acide méthanesufonique dans la précipitation Antarctique: Implications pour le cycle du Soufre aux hautes latitudes, PhD Thesis, Université Joseph Fourier, Grenoble, 260 pp., 1984 (in French).

Field, C. V., Schmidt, G. A., Koch, D., and Salyk, C.: Modeling production and climate-related impacts on ${ }^{10} \mathrm{Be}$ concentration in ice cores, J. Geophys. Res., 111, D15107, https://doi.org/10.1029/2005JD006410, 2006.

Gondwe, M., Krol, M., Gieskes, W., Klaassen, W., and de Baar, H.: The contribution of ocean-leaving DMS to the global atmospheric burdens of DMS, MSA, $\mathrm{SO}_{2}$, and NSS $\mathrm{SO}_{4}$, Global Biogeochem. Cy., 17, 1056, https://doi.org/10.1029/2002GB001937, 2003.

Gondwe, M., Krol, M., Klaassen, W., Gieskes, W., and de Baar, H.: Comparison of modelled versus measured MSA : $\mathrm{NSS} \mathrm{SO}_{4}$ ratios: A global analysis, Global Biogeochem. Cy., 18, GB2006, https://doi.org/10.1029/2003GB002144, 2004.

Heimann, M., Monfray, P., and Polian, G.: Modeling the long-range transport of ${ }^{222} \mathrm{Rn}$ to subantarctic and Antarctic areas, Tellus B, 42, 83-89, 1990.

Hill-Falkenthal, J., Priyadarshi, A., Savarino, J., and Thiemens, M.: Seasonal variations in ${ }^{35} \mathrm{~S}$ and $\Delta^{17} \mathrm{O}$ of sulfate aerosols on the Antarctic plateau, J. Geophys. Res.-Atmos., 118, 9444-9455, https://doi.org/10.1002/jgrd.50716, 2013.

Hoffmann, E. H., Tilgner, A., Schrödner, R., Bräuer, P., Wolke, R., and Herrmann, H.: An advanced modeling study on the impacts and atmospheric implications of multiphase dimethyl sulfide chemistry, P. Natl. Acad. Sci., 113, 11776-11781, https://doi.org/10.1073/pnas.1606320113, 2016.

Huebert, B. J. and Lazrus, A. L.: Bulk Composition of Aerosols in the Remote Troposphere, J. Geophys. Res., 85, 7337-7344, 1980.

Jaffrezo, J. L., Davidson, C. I., Legrand, M., and Dibb, J.: Sulfate and MSA in the air and snow on the Greenland Ice sheet, J. Geophys. Res., 99, 1241-1253, 1994.

Jefferson, A., Tanner, D. J., Eisele, F. L., Davis, D. D., Chen, G., Crawford, J., Huey, J. W., Torres, A. L., and Berresheim, H.: $\mathrm{OH}$ photochemistry and methane sulfonic acid formation in the 
coastal Antarctic boundary layer, J. Geophys. Res., 103, 16471656, 1998.

Johnson, R.: SRS Satellite Contributed Ocean Colour - MODIS - Aqua Chlorophyll Concentration in the Southern Ocean: Monthly, Institute for Marine and Antarctic Studies, ARC Center of Excellence for Climate System Science, Antarctic Climate and Ecosystems Cooperative Research Center, available at: https://portal.aodn.org.au/search?uuid= ce859887-bdf0-4eb0-acf2-80d38af4c85c (last access: 19 February 2017), 2013.

Johnson, R., Strutton, P. G., Wright, S. W., McMinn, A., and Meiners, K. M.: Three improved Satellite Chlorophyll algorithms for the Southern Ocean, J. Geophys. Res.-Oceans, 118, 3694-3703, https://doi.org/10.1002/jgrc.20270, 2013.

Jourdain, B. and Legrand, M.: Seasonal variations of dimethyl sulfide, dimethyl sulfoxide, sulfur dioxyde, methanesulfonate, and non-sea-salt sulfate aerosols at Dumont d'Urville (December 1998-July 1999), J. Geophys. Res., 106, 14391-14408, 2001.

Jourdain, B. and Legrand, M.: Year-round records of bulk and size-segregated aerosol composition and $\mathrm{HCl}$ and $\mathrm{HNO}_{3}$ levels in the Dumont d'Urville (coastal Antarctica) atmosphere: Implications for sea-salt aerosol fractionation in the winter and summer, J. Geophys. Res., 107, 4645, https://doi.org/10.1029/2002JD002471, 2002.

Kerminen, V.-M., Teinilä, K., and Hillamo, R.: Chemistry of seasalt particles in the summer Antarctic atmosphere, Atmos. Environ., 34, 2817-2825, 2000.

Kukui, A., Legrand, M., Ancellet, G., Gros, V., Bekki, S., SardaEstève, R., Loisil, R., and Preunkert, S.: Measurements of $\mathrm{OH}$ and $\mathrm{RO}_{2}$ radicals at the coastal Antarctic site of Dumont d'Urville (East Antarctica) in summer, J. Geophys. Res., 117, D12310, https://doi.org/10.1029/2012JD017614, 2012.

Kukui, A., Legrand, M., Preunkert, S., Frey, M. M., Loisil, R., Gil Roca, J., Jourdain, B., King, M. D., France, J. L., and Ancellet, G.: Measurements of $\mathrm{OH}$ and $\mathrm{RO}_{2}$ radicals at Dome C, East Antarctica, Atmos. Chem. Phys., 14, 12373-12392, https://doi.org/10.5194/acp-14-12373-2014, 2014.

Lazrus, A. L., Cadle, R. D., Gandrud, B. W., Greenberg, J. P., Huebert, B. J., and Rose, W.: Sulfur and halogen chemistry of the stratosphere and of volcanic eruption plumes, J. Geophys. Res., 84, 7869-7875, 1979.

Legrand, M.: Ice-core records of atmospheric sulphur, Philos. T. R. Soc. B, 352, 241-250, 1997.

Legrand, M. and Feniet-Saigne, C.: Methanesulfonic acid in south polar snow layer: A record of strong El Nino, Geophys. Res. Lett., 18, 187-190, https://doi.org/10.1029/90GL02784, 1991.

Legrand, M. and Mayewski, P.: Glaciochemistry of polar ice cores: A review, Rev. Geophys., 35, 219-243, https://doi.org/10.1029/96RG03527, 1997.

Legrand, M. and Pasteur, E. C.: Methane sulfonic acid to non-seasalt sulfate ratio in coastal Antarctic aerosol and surface snow, J. Geophys. Res., 103, 10991-11006, 1998.

Legrand, M., Feniet-Saigne, C., Saltzman, E. S., Germain, C., Barkov, N. I., and Petrov, V. N.: An ice core record of oceanic emissions of dimethylsulfide during the last climatic cycle, Nature, 350, 144-146, https://doi.org/10.1038/350144a0, 1991.

Legrand, M., Sciare, J., Jourdain, B., and Genthon, C.: Daily variations of dimethyl sulfide, dimethyl sulfoxide, methanesulfonate, and non-sea-salt sulfate aerosols at Dumont d'Urville (Decem- ber 1998-March 1999), J. Geophys. Res., 106, 14409-14422, https://doi.org/10.1029/2000JD900840, 2001.

Legrand, M., Preunkert, S., Jourdain, B., Gallée, H., Goutail, F., Weller, R., and Savarino, J.: Year-round record of surface ozone at coastal (Dumont d'Urville) and inland (Concordia) sites in East Antarctica, J. Geophys. Res.-Atmos., 114, D20306, https://doi.org/10.1029/2008JD011667, 2009.

Legrand, M., Preunkert, S., Savarino, J., Frey, M. M., Kukui, A., Helmig, D., Jourdain, B., Jones, A. E., Weller, R., Brough, N., and Gallée, H.: Inter-annual variability of surface ozone at coastal (Dumont d'Urville, 2004-2014) and inland (Concordia, 2007-2014) sites in East Antarctica, Atmos. Chem. Phys., 16, 8053-8069, https://doi.org/10.5194/acp-16-8053-2016, 2016.

Legrand, M., Preunkert, S., Wolff, E., Weller, R., Jourdain, B., and Wagenbach, D.: Year-round records of bulk and sizesegregated aerosol composition in central Antarctica (Concordia site) - Part 1: Fractionation of sea-salt particles, Atmos. Chem. Phys., 17, 14039-14054, https://doi.org/10.5194/acp-17-140392017, 2017.

Mauldin, R. L., Kosciuch, E., Henry, B., Eisele, F. L., Shetter, R., Lefer, B., Chen, G., Davis, D., Huey, G., and Tanner, D.: Measurements of $\mathrm{OH}, \mathrm{HO}_{2}+\mathrm{RO}_{2}, \mathrm{H}_{2} \mathrm{SO}_{4}$, and MSA at the south pole during ISCAT 2000, Atmos. Environ., 38, 5423-5437, 2004.

Minikin, A., Legrand, M., Hall, J., Wagenbach, D., Kleefeld, C., Wolff, E., Pasteur, E. C., and Ducroz, F.: Sulfur-containing spacies (sulfate and methanesulfonate) in coastal Antarctic aerosol and precipitation, J. Geophys. Res., 103, 10975-10990, 1998.

Parish, T. R. and Bromwich, D. H.: Reexamination of the nearsurface airflow over the Antarctic continent and implications on atmospheric circulations at high southern latitudes, Mon. Weather Rev., 135, 1961-1973, 2007.

Pasteur, E. C. and Mulvaney, R.: Migration of methane sulphonate in Antarctic firn and ice, J. Geophys. Res., 105, 11525-11543, 2000.

Piel, C., Weller, R., Huke, M., and Wagenbach, D.: Atmospheric methane sulfonate and non-sea salt sulphate records at the EPICA deep-drilling site in Dronning Maud Land, Antarctica, J. Geophys. Res., 111, D03304, https://doi.org/10.1029/2005JD006213, 2006.

Preunkert, S., Jourdain, B., Legrand, M., Udisti, R., Becagli, S., and Cerri, O.: Seasonality of sulfur species (dimethyl sulfide, sulfate, and methanesulfonate) in Antarctica: Inland versus coastal regions, J. Geophys. Res., 113, D15302, https://doi.org/10.1029/2008JD009937, 2008.

Raisbeck, G. M., Yiou, F., Fruneau, M., Loiseaux, J. M., Lieuvin, M., and Ravel, J. C.: Cosmogenic ${ }^{10} \mathrm{Be} /{ }^{7} \mathrm{Be}$ as a probe of atmospheric transport processes, Geophys. Res. Lett., 8, 1015-1018, 1981.

Rankin, A. M. and Wolff, E. W.: A year-long record of sizesegregated aerosol composition at Halley, Antarctica, J. Geophys. Res., 108, 4775, https://doi.org/10.1029/2003JD003993, 2003.

Read, K. A., Lewis, A. C., Bauguitte, S., Rankin, A. M., Salmon, R. A., Wolff, E. W., Saiz-Lopez, A., Bloss, W. J., Heard, D. E., Lee, J. D., and Plane, J. M. C.: DMS and MSA measurements in the Antarctic Boundary Layer: impact of $\mathrm{BrO}$ on MSA production, Atmos. Chem. Phys., 8, 2985-2997, https://doi.org/10.5194/acp8-2985-2008, 2008. 
Rugel, G., Pavetich, S., Akhmadaliev, S., Enamorado Baez, S. M., Scharf, A., Ziegenrücker, R., and Merchel, S.: The first four years of the AMS-facility DREAMS: Status and developments for more accurate radionuclide data, Nucl. Instrum. Meth. B, 370, 94-100, 2016.

Saigne, C. and Legrand, M.: Measurements of methanesulphonic acid in Antarctic ice, Nature, 330, 240-242, 1987.

Saltzman, E. S., Savoie, D. L., Prospero, J. M., and Zika, R. G.: Methanesulphonic acid and non-sea-salt sulphate in Pacific air: Regional and seasonal variations, J. Atmos. Chem., 4, 227-240, 1986.

Shaw, G. E.: Bio-controlled thermostasis involving the sulfur cycle, Clim. Change, 5, 297-303, 1983.

Simo', R. and Dachs, J.: Global ocean emission of dimethylsulfide predicted from biogeophysical data, Global Biogeochem. Сy., 16, 1018, https://doi.org/10.1029/2001GB001829, 2002.

Udisti, R., Becagli, S., Benassai, S., Castellano, E., Fattori, I., Innocenti, M., Migliori, A., and Traversi, R.: Atmosphere-snow interaction by a comparison between aerosol and uppermost snow layers composition at Dome C (East Antarctica), Ann. Glaciol., 39, 53-61, 2004.

von Glasow, R. and Crutzen, P. J.: Model study of multiphase DMS oxidation with a focus on halogens, Atmos. Chem. Phys., 4, 589608, https://doi.org/10.5194/acp-4-589-2004, 2004.

Wagenbach, D., Görlach, U., Moser, K., and Münnich, K. O: Coastal Antarctic aerosol: the seasonal pattern of its chemical composition and radionuclide content, Tellus B, 40, 426-436, 1988.

Wagenbach, D.: Coastal Antarctica: atmospheric chemical composition and atmospheric transport, in: Chemical Exchange between the Atmosphere and polar snow, NATO ASI Series Volume 43, edited by: Wolff, E. W. and Bales, R. C., Springer-Verlag, Berlin, Heidelberg, 173-199, 1996.

Wagenbach, D., Ducroz, F., Mulvaney, R., Keck, L., Minikin, A., Legrand, M., Hall, J. S., and Wolff, E. W.: Sea-salt aerosol in coastal Antarctic regions, J. Geophys. Res., 103, 10961-10974, https://doi.org/10.1029/97JD01804, 1998.
Wagnon, P., Delmas, R., and Legrand, M.: Loss of volatile acid species from upper firn layers at Vostok, J. Geophys. Res., 104, 3423-3431, 1999.

Welch, K. A., Mayewski, P. A., and Whitlow, S. I.: Methanesulfonic acid in coastal Antarctic snow related to sea-ice extent, Geophys. Res. Lett., 20, 443-446, 1993.

Weller, R. and Wagenbach, D: Year-round chemical aerosol records in continental Antarctica obtained by automatic sampling, Tellus B, 59, 755-765, 2007.

Weller, R., Traufetter, F., Fischer, H., Oerter, H., Piel, C., and Miller, H.: Post depositional losses of methanesulfonate, nitrate and chloride at the EPICA deep-drilling site in Dronning Maud Land, Antarctica, J. Geophys. Res., 109, D07301, https://doi.org/10.1029/2003JD004189, 2004.

Weller, R., Levin, I., Schmithüsen, D., Nachbar, M., Asseng, J., and Wagenbach, D.: On the variability of atmospheric ${ }^{222} \mathrm{Rn}$ activity concentrations measured at Neumayer, coastal Antarctica, Atmos. Chem. Phys., 14, 3843-3853, https://doi.org/10.5194/acp14-3843-2014, 2014

Wolff, E., Hall, J., Mulvaney, R., Pasteur, E., Wagenbach, D., and Legrand, M.: Relationship between chemistry of air, fresh snow and firn cores for aerosol species in coastal Antarctica, J. Geophys. Res., 103, 11057-11070, 1998.

Wolff, E. W., Fischer, H., Fundel, F., Ruth, U., Twarloh, B., Littot, G. C., Mulvaney, R., Rothlisberger, R., de Angelis, M., Boutron, C. F., Hansson, M., Jonsell, U., Hutterli, M. A., Bigler, M., Lambert, F., Kaufmann, P., Stauffer, B., Stocker, T. F., Steffensen, J. P., Siggaard-Andersen, M. L., Udisti, R., Becagli, S., Castellano, E., Severi, M., Wagenbach, D., Barbante, C., Gabrielli, P., and Gaspari, V.: Southern Ocean sea-ice extent, productivity and iron flux over the past eight glacial cycles, Nature, 440, 491-496, 2006.

Zhu, L., Nicovich, J. M., and Wine, P. H.: Kinetics Studies of Aqueous Phase Reactions of $\mathrm{Cl}$ Atoms and $\mathrm{Cl}_{2}^{-}$Radicals with Organic Sulfur Compounds of Atmospheric Interest, J. Phys. Chem. A, 109, 3903-3911, 2005. 